\title{
A CISÃO COGNITIVA DO PROCESSO OBJETIVAMENTE COMPLEXO: A EVOLUÇÃO HISTÓRICA DA CISÃO COGNITIVA E O ATUAL PANORAMA NO CPC/2015
}

\section{THE COGNITIVE FISSION OF THE OBJECTIVELY COMPLEX PROCESS: THE HISTORICAL EVOLUTION OF COGNITIVE SPLIT AND THE CURRENT PANORAMA IN THE CPC/2015}

Vinícius da Silva Lemos Doutor em Direito Processual pela UNICAP. Mestre em Sociologia e Direito pela UFF. Especialista em Processo Civil pela FARO. Professor de Processo Civil na FARO e UNIRON. Presidente do Instituto de Direito Processual de Rondônia - IDPR. Membro da Associação Norte-Nordeste de Professores de Processo - ANNEP. Membro do Centro de Estudos Avançados em Processo - CEAPRO. Membro da Academia Brasileira de Direito Processual Civil - ABDPC. Membro da Associação Brasileira de Direito Processual ABDPRO. Membro da Instituto Brasileiro de Direito Processual - IBDP. Advogado. Porto Velho/Rondônia. Email: viniciuslemos.ro@gmail.com.

RESUMO: O presente trabalho tem como propósito e objetivo a análise sobre a cisão cognitiva num processo objetivamente complexo no processo civil brasileiro, partindo de um estudo sobre a evolução do direito positivo processual e a sua relação com a cisão cognitiva, seja mediante a sua excepcionalidade nas codificações processuais anteriores, seja mediante a vigência da teoria da unicidade da sentença, seja no panorama atual, mediante a positivação das decisões parciais no Código de Processo Civil de 2015.

PALAVRAS-CHAVE: processo objetivamente complexo; cisão cognitiva; evolução histórica, panorama atual; decisão parcial.

\footnotetext{
${ }^{1}$ Artigo recebido em 08/12/2020 e aprovado em 05/04/2021.
} 
ABSTRACT: The present work has as its purpose and objective analysis of the cognitive fission in a complex process objectively in Brazilian civil procedure, starting with a study on the evolution of positive law procedure and its relationship with the cognitive fission, either through their exceptionality in previous procedural encodings, either upon the validity of the theory of the oneness of the sentence, either in the current perspective, upon the positivization of partial decisions in the Civil Procedure Code of 2015.

KEYWORDS: process objectively complex; cognitive fission; historical evolution, current perspective; partial decision.

\section{INTRODUÇÃO}

$\mathrm{Na}$ história do processo civil brasileiro, o princípio da oralidade era de grande importância no caminhar procedimental, culminando na grande concentração de atos para a audiência de instrução e julgamento, com a teoria da unicidade da sentença.

Mediante esse ponto, no procedimento comum, principalmente no ordinário do CPC/73, todos os pedidos de um processo objetivamente complexo deveriam ser julgados somente no ato sentencial, por mais que um ou outro pudesse já ser resolvido. Não havia sentido de uma cisão cognitiva.

Apesar dessa escolha pela unicidade da sentença no procedimento comum, alguns procedimentos especiais existiam exatamente para permitir a cisão cognitiva e a possibilidade de prolatar duas sentenças em uma só processo. Ou seja, não é novidade na processualística brasileira a existência da cisão cognitiva, contudo sempre era relegada ao campo da exceção.

Na evolução do conceito de sentença e as alterações realizadas no ordenamento processual revogado, a cisão cognitiva e a possibilidade de decisões parciais foram dialogando com o procedimento comum. No CPC/2015, a positivação das decisões parciais no processo civil brasileiro, diante dos arts. 354, parágrafo único e 356.

$\mathrm{O}$ presente estudo descreve o processo objetivamente complexo e investiga o histórico evolutivo da cisão cognitiva até a positivação no atual ordenamento, com as 
diretrizes e perspectivas da utilidade do instituto e o diálogo com os procedimentos especiais atuais.

\section{O PROCESSO OBJETIVAMENTE COMPLEXO NO DIREITO PROCESSUAL BRASILEIRO}

\subsection{Conceito de processo objetivamente complexo}

Uma demanda pode ser simples ou objetivamente complexa.

A simples será uma pretensão deduzida no processo que tem como partes um autor e um réu. O transcorrer do procedimento está envolto sempre a uma unidade, a decorrer, $a$ priori, uma processualística mais simples. Ao contrário, a objetivamente complexa é aquela demanda em que existem pluralidade de pedidos ou de partes naquela pretensão, com uma série de demandas a serem expostas ao mesmo tempo, com a necessidade do juízo responder todos os pleitos ali existentes na demanda, mediante a complexidade das próprias relações jurídicas levadas à jurisdição.

Obviamente que o processo civil é voltado, em sua maioria construtiva, a organizar um processo de modo simples, a pensar primeiro numa evolução gradual para o entendimento da simplicidade e, somente após, com alguns dispositivos autorizantes de menção à complexidade. Um exemplo seria os dispositivos da petição inicial, num primeiro momento se explica o pedido, como uníssono e, posteriormente, dispõe que é possível cumular estes, saindo de um processo simples para um processo complexo.

Ainda assim, não se tem uma grande construção na norma ${ }^{2}$ das diversas diferenças que a cumulação de partes ou de pedidos proporciona ao processo, com a necessária construção da doutrina - ao imaginar problemas hipotéticos - e da jurisprudência - ao lidar com problemas concretos - sobre eventuais lacunas existentes e confusões procedimentais, justamente para tornar a demanda apta ao processamento de processos complexos da melhor maneira possível.

\footnotetext{
Barbosa Moreira já dizia sobre essa falta de estudo sobre o tema das sentenças objetivamente complexas: "O problema insere-se em temática sobre a qual a doutrina em geral não se tem debruçado com grande interesse: a das denominadas sentenças objetivamente complexas.” BARBOSA MOREIRA, José Carlos. Sentença objetivamente complexa, trânsito em julgado e rescindibilidade. Revista Dialética de Direito Processual. Vol. 45, São Paulo: Dialética, dez/2006. p. 54.
} 
De todo modo, é uma matéria ainda pouco explorada no todo, apesar de ser um tanto delineada e explorada em pesquisas de alguns pontos reflexos, como: coisa julgada; capítulos da sentença; recurso parcial, etc.

Se o problema no mundo fenomênico traz em si, para as partes envolvidas, uma série de pedidos $^{3}$ e relações jurídicas, isso torna o objeto do processo - seja no modo amplo, seja no objeto litigioso do processo - complexo, com o trâmite procedimental exigindo uma real adequação a cada peculiaridade, tais como a adequação da petição inicial a tratar de todos os pedidos e suas causas de pedir, inclusive com a junção de todos os valores para mensurar a causa; na contestação o réu deve torná-la uma peça hábil a rebater todos os pedidos do autor e suas argumentações; na admissibilidade da demanda, cada pedido conterá seus próprios pressupostos; no saneamento, cada vício deve ater-se, se existente, ao impacto específico em cada pedido, em cada relação, bem como os pontos controvertidos trabalham na mesma órbita de impactos igualmente correspondentes; e, assim se desencadeia o impacto dessa complexidade no objeto da demanda, delineando o andar do restante da demanda, em todo o seu transcorrer.

A complexidade inicia-se na cumulação da demanda, seja pela pluralidade de pedidos, seja na pluralidade de partes. Uma vez que o autor cumula pedidos em sua petição inicial, não será somente uma pretensão deduzida em juízo, serão quantas forem pleiteadas, cada qual com a exigência de resposta sobre o acolhimento ou não, bem como sobre a sua admissibilidade específica.

Essa cumulação de pedidos pode ser em momento ulterior, pelo réu, por exemplo, também tornando o processo complexo em seu objeto em eventual reconvenção ou pedido contraposto.

A pluralidade de partes - fora o litisconsórcio unitário ${ }^{4}$ - enseja também uma pluralidade de relações jurídicas em juízo, com cada qual representando um objeto diverso

Também será uma sentença objetivamente complexa se o pedido for somente um, contudo haja a possibilidade de ser decomponível, o que torna a sua possibilidade de procedência parcial e, assim, uma cisão interna do próprio pleito. "Complicam as coisas quando, divisível que seja a prestação, o juiz só em parte acolhe o pedido.” BARBOSA MOREIRA, José Carlos. Sentença objetivamente complexa, trânsito em julgado e rescindibilidade. Revista Dialética de Direito Processual. Vol. 45, São Paulo: Dialética, dez/2006. p. 55.

4 "um só pedido e uma só decisão, embora endereçada simultaneamente a dois, a três ou a vários." DINAMARCO, Cândido Rangel. Capítulos de sentença. $3^{a}$. ed. São Paulo: Malheiros, 2008. p. 74. 
e, por isso, necessário ser considerado complexo para a construção dos argumentos das partes, produção de provas, atos processuais até a sentença e sua recorribilidade.

No tocante à sentença e qualquer outra decisão, quando um processo é complexo, cada pronunciamento judicial passa a ter a exigência de relacionar-se com um todo ou com somente alguns pontos da demanda, o que imporá do juízo uma responsabilidade cooperativa maior ${ }^{5}$ sobre a percepção cognitiva daquela demanda complexa, se resolve questões que impactam todo o processo e seu conteúdo ou somente parcela deste.

É complexa uma demanda aquela que enseja a prolação de uma sentença que contenha mais de uma decisão interna em seu mérito ${ }^{6}$. Obviamente que a cumulação enseja essa pluralidade de decisões no ato decisório, o que proporciona essa complexidade, mas não será somente a pluralidade dos pedidos que fará com que o processo seja complexo, uma vez que essa complexidade se inter-relaciona com a teoria dos capítulos da sentença. Mesmo que seja um só pedido, pode haver uma diversidade de capítulos, como a divisão entre capítulos de questões processuais e de mérito, gerando, de igual maneira, uma decisão macro como um conjunto de decisões fracionadas ${ }^{7}$.

Diante disso, há uma relação entre a quantidade de pedidos e a quantidade de decisões naquela demanda, bem como a própria análise de questões processuais ${ }^{8}$ pode tornar a decisão igualmente complexa.

5 "a concretização do princípio da cooperação e, no caso, também de uma concretização do princípio do contraditório, que assegura aos litigantes o poder de influenciar na solução da controvérsia. Como se sabe, ao magistrado a investigação oficial de algumas questões (como por exemplo, os pressupostos processuais e as condições da ação, ex vi do $\S 3^{\circ}$ do art. 267 do CPC), o respeito a este dever revela-se fundamental." DIDIER JR., Fredie. Os três modelos de direito processual: inquisitivo, dispositivo e cooperativo. Revista de Processo. Vol. 198, Ano 36, p. 213-225, São Paulo: Ed. RT, 2011. p. 219.

6 "Numa primeira aproximação, poderiam assim definir-se as sentenças cujo dispositivo contém mais de uma decisão. Também seria possível caracterizar a sentença objetivamente complexa aquela que se compõe de mais de um capítulo." BARBOSA MOREIRA, José Carlos. Sentença objetivamente complexa, trânsito em julgado e rescindibilidade. Revista Dialética de Direito Processual. Vol. 45, São Paulo: Dialética, dez/2006. p. 54.

7 "São objetivamente complexas as decisões cujo dispositivo pode ser fracionado em capítulos." DIDIER JR., Fredie; BRAGA, Paula Sarno; OLIVEIRA, Rafael Alexandria de. Curso de processo civil. Vol. 2. 10a. ed. Salvador: Juspodivm, 2015. p. 394.

8 Sobre a quantidade de questões que devem ser analisadas pelo juízo, tanto as processuais, quanto as de direito e, estas, sendo maior do que o objeto litigioso do processo: "Mas a cognição do juiz ultrapassa o objeto litigioso, porque além desses três elementos, cabe ainda ao juiz examinar conclusivamente as questões de direito material suscitadas pelo réu, a chamada causa excipiendi, que em conjunto com aqueles compõem o mérito, ou seja, todas as questões de direito material; vai mais além essa cognição, incluindo ainda as questões processuais e relativas à existência do direito de ação e ao impulsionamento do processo. Temos, pois, de distinguir o objeto da jurisdição (o pedido), o objeto litigioso (partes, pedido e causa de pedir), o mérito, como conjunto de questões de direito material (o objeto litigioso + a 
No entanto, não será somente esses dois pontos - pedido e capítulos - que tornam a demanda e a sentença objetivamente complexa. Igualmente deve-se entender que a cognição judicial se dará sobre questões, as quais também podem se multiplicar na demanda.

Como já exposto, a cognição judicial é o ato inteligível do juiz ao conhecer de questões colocadas para sua apreciação durante o transcorrer processual ${ }^{9}$ passa a entender as controvérsias em torno destas, conhecendo-as e enfrentando-as, com a aptidão de resolvê-las como meio de preparar-se para decidir a pretensão deduzida no processo através do pedido do autor - ou do réu, se for em reconvenção ou em pedido contraposto.

Dessa maneira, um processo que detém somente autor e réu, com um pedido, pode gerar várias questões processuais ou incidentes que ensejem capítulos próprios da decisão, tornando-a complexa, com a necessidade de cognição sobre cada um destes pontos argumentativos.

Há uma relação primordial entre pedido, capítulos e cognição. Quanto mais pedidos - mesmo que seja pela pluralidade de partes, mais capítulos e, consequentemente, mais desdobramentos em questões cognitivas a serem enfrentadas, tornando a sentença complexa objetivamente.

Mesmo que possa ter uma demanda somente com um pedido e pluralidade de questões que torne a sentença complexa objetivamente, a relação pedido/capítulo/cognição não será completa, mas nem por isso não será complexa a sentença. $\mathrm{O}$ desenvolvimento aqui exposto é que essa tríade torna necessariamente uma sentença complexa objetivamente, contudo há a possibilidade dessa complexidade existir em situações de pluralidade de questões, sem ter cumulação de pedidos ou vice-versa.

Todavia, o intuito é demonstrar que o processo com objeto complexo gera uma outra visão de processualística, com pluralidade decisória, o que importa em outra ótica sobre o processo e seu procedimento, com uma ampla diversidade de acepções em pontos processuais de modo diverso a um processo simples.

\section{A VISÃO CONCEITUAL DA CISÃO COGNITIVA}

causa excipiendi), e o objeto da cognição (pressupostos processuais, condições da ação e mérito)." GRECO, Leonardo. A teoria da ação no processo civil. São Paulo: Dialética, 2003. p. 47.

9 WATANABE, Kazuo. Da cognição no processo civil. $3^{\text {a }}$. ed. São Paulo: Perfil, 2005. p. 67. 


\subsection{0 conceito de cisão cognitiva}

A cognição judicial está dividida em diversas questões a serem solucionadas para que se possa alcançar o julgamento do próprio mérito, a resposta ao pedido realizada pelo autor como pleito à jurisdição. Para que seja possível a atividade cognitiva do mérito da demanda é necessário ultrapassar a questão de admissibilidade e, ainda, se for o caso, outras questões prévias.

No entanto, num processo objetivamente complexo, com várias relações jurídicas existentes, cada capítulo autônomo da demanda gera uma cognição à parte, com a necessidade de que seja analisada de modo em separado sobre cada ponto da sentença.

De certa maneira, a complexidade objetiva da demanda leva a uma série de análises a serem realizadas cognitivamente pelo julgador no momento em que for prolatar a decisão, contudo a estrutura processual está moldada para que seja prolatada, via de regra, uma única decisão, a prolação de uma sentença com a cognição exauriente de todos os pedidos e relações jurídicas existentes entre as partes.

$\mathrm{Na}$ autonomia dos capítulos da demanda e da sentença já se encontra uma cisão cognitiva interna da sentença, uma vez que cada capítulo é autônomo em relação a outro capítulo, o que leva cada cognição, se for o caso, a ser realizada de modo igualmente autônomo, mesmo que seja proferida na mesma decisão.

Todavia, a possibilidade de uma cisão cognitiva está na visão de que as cognições sobre capítulos autônomos sejam realizadas em momentos procedimentais separados, com a quebra da unicidade da prolação de somente uma decisão no procedimento, com a desnecessidade de que todos os capítulos sejam decididos em um só momento.

A conceituação de uma cisão cognitiva está na existência de um processo objetivamente complexo que pode conter dois ou mais momentos decisórios, com o desmembramento - cindibilidade - em decisões atinentes somente a uma parcela do processo originalmente proposto - ou ulteriormente composto. Uma vez possível que parcela da demanda seja julgada, sem a mesma possibilidade quanto aos demais pontos, cinde-se a cognição para que seja viável a prestação jurisdicional já apta a ser realizada, com o prosseguimento do que não for possível naquele momento.

Essa cisão é possível claramente dada a positivação dos arts. 354, parágrafo único e 356, ambos do CPC. No procedimento comum, no ordenamento anterior, não era 
claramente possível essa cisão cognitiva, apesar de defensável pelas hipóteses encontradas nos casos em concreto e na evolução do direito processual.

No entanto, mesmo no CPC/73, era possível a cisão cognitiva nos procedimentos especiais, o que demonstra que essa cisão não era estranha ao ordenamento, somente relegada a necessidade de positivação específica e diferenciação procedimental para que fosse cabível na processualística brasileira.

E, ainda, a evolução do direito processual, com as alterações legislativas realizadas no CPC/73 no decorrer do tempo, a cisão cognitiva passou a ser ainda mais viável no procedimento comum, o que diferenciava tanto do texto legal original do ordenamento anterior quanto da sua possibilidade no procedimento especial.

Necessário, portanto, o enfrentamento dessa evolução sobre a cisão cognitiva no processo civil brasileiro.

\section{A EVOLUÇÃO DA CISÃO COGNITIVA NO DIREITO POSITIVO BRASILEIRO}

\subsection{A visão da unicidade da sentença como regra restritiva no procedimento comum no $\mathrm{CPC} / 73$}

No ordenamento processual anterior, mesmo diante de um processo objetivamente complexo, com a divisão em capítulos, a sentença era una, com um só ato, mediante a necessidade de uma prolação decisória que integrasse a demanda como um todo.

Mediante essa regra da unicidade, para o devido entendimento dessa teoria, o pensamento de Chiovenda e Liebman devem ser revisitados sobre o tema.

Essa ideia de somente um julgamento de mérito para a prestação jurisdicional foi a partir da incorporação no CPC/73 da visão de Chiovenda de que a processualística deveria desenvolver-se de maneira oral ${ }^{10}$, numa audiência de instrução como prioridade e, desse modo, concentrar as decisões sobre os pedidos do autor para só momento.

O principal intuito era não possibilitar que o processo fosse demasiadamente formal e escrito, utilizando-se da oralidade para que o juiz tivesse maior contato com os atores

10 No sentido da oralidade como base processual: CHIOVENDA, Giuseppe. La idea romana en el proceso civil moderno. In: CHIOVENDA, Giuseppe. Ensayos de derecho procesal civil. Vol. I, p. 351-372, Buenos Aires: Ediciones Jurídicas Europa-América, 1949. 
processuais $^{11}$, mediante a imaginação de que este juiz deveria ser o mesmo em todo o processo, atrelando sua identidade física ao julgamento, com o devido acompanhamento da produção das provas e, se possível, a concentração desses atos numa audiência, culminando na prolação da sentença sobre todo o processo.

Diante dessa visão de processo baseado na oralidade de Chiovenda, a teoria da unicidade da sentença era válida, baseada ainda com a sua visão pela irrecorribilidade das decisões interlocutórias ${ }^{1213}$.

Com essas regras postas, a teoria da unicidade da sentença era salutar e natural, com a concentração de muitos atos em um só, bem como a facilitação da produção de provas, incluindo também a irrecorribilidade das interlocutórias ${ }^{14}$ e a concentração da resolução das questões na sentença. Com oralidade, rapidez e concentração dos atos, não haveria motivos de admitir-se que uma sentença ou os pedidos que foram realizados pelo autor seriam bipartidos ou cindidos, dada a excelência de pensamento processual, com celeridade e duração razoável.

O posicionamento de Chiovenda era inserto no CPC/39 dada a redação dos arts. 270 e $271^{15}$ daquele ordenamento processual, quando dispunham que haveria uma audiência de instrução e julgamento contínua, com a realização da instrução probatória, os debates e o julgamento, num só dia.

Com o encerramento do debate, o juiz proferia a sentença.

11 Corroborando a visão da oralidade advinda de Chiovenda: MARINONI, Luiz Guilherme. Técnica processual e tutela dos direitos. São Paulo: Ed. RT, 2004. p. 141/142.

12 A visão da teoria da unicidade da sentença como também uma visão de concentração dos atos processuais: "Ao elaborar o princípio da unidade da sentença, Chiovenda tinha em mente um outro princípio, qual seja, o da concentração. O princípio da concentração foi concebido para que as atividades processuais se concentrem em breve período de tempo e se desdobrem sem interrupção, resolvendo-se os incidentes em ato contínuo, no intuito de assegurar a continuidade do processo." SANT'ANNA, Paulo Afonso de Souza. Sentença parcial. Revista de Processo. Vol. 151, Ano, 33, p. 150-184, São Paulo: Ed. RT, 2007. p. 151.

13 Hoje essa visão está mais atrelada ao processo do trabalho, desde a oralidade, unicidade, irrecorribilidade das decisões interlocutórias, concentração de atos em audiência.

14 CINTRA, Antônio Carlos de Araújo; DINAMARCO, Cândido Rangel; GRINOVER, Ada Pellegrini. Teoria geral do processo. $26^{\text {a }}$. ed. São Paulo: Malheiros, 2010. p. 326.

15 CPC - 1939. Art. 270. A audiência será contínua, e só por motivo de força maior se interromperá. Não sendo possível concluir a instrução, o debate e o julgamento num só dia, o juiz, independentemente de novas intimações, marcará a continuação para dia próximo.

Art. 271. Encerrado o debate, o juiz proferirá a sentença. Parágrafo único. Se não se julgar habilitado a decidir a causa, designará, desde logo, outra audiência, que se realizará dentro de dez (10) dias, afim da publicar a sentença. 
Logo, se a regra era uma audiência de instrução e julgamento, a oralidade era importante e presente, bem como todas as assertivas que Chiovenda entendia como importantes para o processo, como o mesmo juiz instruir e julgar, a imediatividade da inteiração entre as partes, os procuradores e o juiz, concentrando seu andamento, relacionando-se com as partes e com as decisões interlocutórias, em regra, não sendo recorríveis ${ }^{16}$. Chiovenda entendia que toda essa oralidade e aproximação de um juiz específico traria maiores benefícios ao procedimento e, assim, desnecessário seria a prolação de sentenças parciais, concentrando para um só ato processual.

Com a oralidade como base do processo civil, sem motivos para a prolação de sentenças parciais e a divisão procedimental entre parcela da demanda em via recursal e a outra em primeiro grau, com a possibilidade de um conteúdo influenciar o seguinte. A concentração dos atos decisórios só numa sentença contribuiria para o andamento processual e para a correta divisão entre os momentos de atribuição do primeiro e do segundo grau ${ }^{17}$.

Com base na oralidade e concentração de atos na audiência de instrução, naturalmente o CPC/39 adotava a teoria da unicidade da sentença, como o único momento para a decisão sobre o acolhimento ou não dos pedidos do autor. No entanto, mesmo positivado no CPC/39, o princípio da oralidade não teve o impacto almejado, pela própria

16 Sobre a irrecorribilidade das interlocutórias: "Com o claro objetivo de solucionar essa situação, que era vista como um defeito do sistema então vigente (CPC italiano de 1865), o modelo de processo oral chiovendiano baseava-se nos princípios (i) da imediatidade da relação do juiz com os jurisdicionados, (ii) da identidade física do juiz, (iii) da concentração e (iv) da irrecorribilidade das interlocutórias, dentre outros." CORREIA FILHO, Antonio Carlos Nachif. Julgamentos parciais no processo civil. São Paulo, SP, 2015. 176 p. Dissertação (Mestrado). Universidade de São Paulo. Programa de Pós-Graduação em Direito. p. 32.

17 A relação entre a unicidade da sentença e os recursos é explicada por Marques. Faz sentido essa visão de que uma só decisão melhora a sistemática única recursal, mas nos leva a imaginar se a decisão pode ser adiada somente por causa do seu recurso impugnativo? A resposta tende a ser não, inapropriado que o recurso seja a base influenciante de um ato antecedente."Formado o processo cumulativo, não pode o juiz decidir antecipadamente um ou alguns dos litígios e deixar os demais para a sentença a ser proferida a final. Todos os litígios devem ser julgados numa só sentença (sentença antecipada sobre a lide ou sentença em audiência), uma vez que não se pode suspender o curso do procedimento em havendo apelação, com efeito suspensivo, para aguardar o julgamento do recurso. E como seria absurdo, contra ius e contra legem, entender-se que aí caberia o agravo de instrumento, - o princípio da economia processual (que é um dos inspiradores do art. 330) impede aquela suspensão do processo cumulativo, e, consequentemente, julgamento antecipado de apenas uma ou algumas das lides contidas em simultâneos processos.” MARQUES, José Frederico. Manual de direito processual civil. Vol. II, $2^{\text {a }}$ ed., Rio de Janeiro: Saraiva, 1976. p. 165. 
incapacidade de efetivação pelo Judiciário, pela morosidade existente e o estoque de demandas nas crises do próprio sistema.

Como consequência a oralidade foi diminuída na construção do $\mathrm{CPC} / 73$, com a continuidade da audiência de instrução e julgamento como o momento chave para a produção de provas, contudo mitigou-se quando se permitiu diversas exceções, como o julgamento antecipado da lide, em hipóteses em que era dispensada a audiência de instrução e julgamento, com sentença prolatada desde $\log { }^{18}$.

Fora isso, o cotidiano forense demonstrou que era inviável engessar o processo e o seu andamento com a identidade física do juiz, quebrando o que se entendia como primordial sobre o imediatismo da noção do juiz sobre a percepção do que se produziu, sem ater-se a relatórios existentes, mas com a vivência da própria produção de provas.

Diante de tais inovações no $\mathrm{CPC} / 73$, o princípio da oralidade foi menos prestigiado e, consequentemente, o processo com sua morosidade trabalha em outro centro, em outro prisma, sem ater-se na audiência como base para a cognição do juízo.

Outro ponto da transição do CPC/39 para o CPC/73 foi a amplitude da recorribilidade das decisões interlocutórias, o que Chiovenda entendia como necessário para que a oralidade fosse a base para o processo civil, com uma duração mais arrastada, como de fato a prática demonstrou, a tendência foi liberar a recorribilidade das interlocutórias ${ }^{19}$, com a possibilidade no art. 522 do $\mathrm{CPC} / 73$ abrindo para qualquer hipótese de decisão interlocutória o cabimento do agravo de instrumento.

18 Sobre julgamento antecipado no CPC/73 e a dispensa da audiência preliminar, também dependiam da necessidade de produção de prova ou não, mediante a definição ou possibilidade de resolução das questões de fato. "Se existem questões de fato no processo, mas essas são estranhas à questão principal, é de se aplicar a regra que autoriza o julgamento antecipado da lide. Isto porque a dispensa da audiência ocorrerá quando existirem fatos relevantes para a decisão da causa que não dependam de prova. Se houver requerimentos de prova acerca de fatos irrelevantes, ou estando os relevantes devidamente provados, é, da mesma forma, de se proceder ao julgamento antecipado da lide." ALVIM, Alvim. Manual de direito processual civil. Vol. II, 6ª ed., São Paulo: Ed. RT, 1997. p. 381/382.

19 Chiovenda defendia a unicidade da sentença como o corolário da efetivação do princípio da oralidade e concentração do processo, o que tornaria inviável, inusual e desnecessária a bipartição do processo. "Ora, eu adverti mais de uma vez que a proibição de apelação imediata das interlocutórias é compreensível e útil na medida em que constitua uma partícula do processo oral, quer dizer, um adminículo indispensável para assegurar a concentração. Fora daí, é desarrazoado e prejudicial." CHIOVENDA, Giuseppe. Instituições de direito processual civil. Vol. 3. Campinas-SP: Bookseller. 1998. p. 237. 
Diante desses pontos, a construção da teoria da unicidade da sentença para Chiovenda não merecia mais subsistir mesmo no ordenamento revogado ${ }^{20}$. No entanto, Liebman, também responsável por essa visão, sustentava os arts. 458, II e 459 do CPC/73 como os representantes legais da concentração dos atos decisórios sobre o pleito do autor na sentença.

Os arts. 458, II e 459 do CPC/73 tinham o condão de conceder base legal para essa teoria no entendimento de Liebman pelo fato de disporem, em conjunto, que na sentença constariam os fundamentos de análise sobre as questões de fato e de direito e a resposta sobre a acolhida, ou não, em todo ou em parte, o pedido do autor ${ }^{21}$.

O posicionamento era sobre a sentença ser o ato pelo qual o juiz colocava termo ao processo, decidindo ou não o mérito da causa, como disposto na redação original do CPC/73, quando o art. $162, \S 1^{\circ}$ especificava claramente: "sentença é o ato pelo qual o juiz põe termo ao processo, decidindo ou não o mérito da causa."

Ou seja, numa análise temporal, o conceito de sentença era de um ato único de encerramento da jurisdição, quando o juízo de primeiro grau, ao analisar se decide o processo com ou sem o mérito, colocando fim ao processo. $\mathrm{O}$ ato sentencial estava atrelado ao ato de encerramento da análise pelo juízo, separando entre uma decisão terminativa ou definitiva, com o fim do processo.

Essa conceituação baseava-se, diante de tal dispositivo, em dois pontos que na época faziam sentido: (i) a completa cisão procedimental entre o processo de

20 Sobre a derrocada da oralidade como base central do processo civil brasileiro e, com isso, a desnecessidade da unicidade da sentença: "o projeto de Chiovenda, ligado à oralidade, esvaziou-se tanto na Itália quanto no Brasil. A falta de estrutura do Poder Judiciário para dar conta das inúmeras causas apresentadas tornou impossível a concentração dos atos processuais, enquanto a demora do processo trouxe grande dificuldade para a implementação da identidade física, o que, por consequência lógica, reduziu a zero o benefício que poderia ser trazido pela imediatidade" MARINONI, Luiz Guilherme. Técnica processual e tutela dos direitos. São Paulo: Ed. RT, 2004. p. 141/142.

21 Sobre a unicidade e concentração da sentença: "atrelando a ideia de sentença à conclusão do processo, automaticamente vetava a possibilidade de sentenças parciais e sucessivas. Aludia-se também aos artigos 458, II, e 459 - cuja redação segue inalterada, evidenciando a atualidade da discussão -, enxergando-se neles o dever de concentração" AMBRIZZI, Tiago Ravazzi. Julgamento fracionado do mérito no processo civil brasileiro. São Paulo, SP, 2014. 231 p. Dissertação (Mestrado). Universidade de São Paulo. Programa de Pós-Graduação em Direito. p. 78. 
conhecimento e de execução, com a necessidade de outra petição inicial e citação ${ }^{22}$; (ii) a visão de prestação jurisdicional una.

$\mathrm{O}$ primeiro aspecto era a realidade do processo imaginado no $\mathrm{CPC} / 73$ quando a sentença encerrava a prestação jurisdicional em primeiro grau e o julgamento de eventual recurso igualmente encerrava nos Tribunais. Não havia mais aquele processo depois do trânsito em julgado, apesar de formar coisa julgada e título executivo, este deveria ser executado com novos trâmites processuais, ainda que utilizando da prevenção e do mesmo processo, tanto que havia a necessidade de nova citação da parte a ser executada.

Outro aspecto era a definição de que o juízo ao sentenciar o faria respondendo ao mérito ou decidindo sem resolução deste. Em contrapartida, a conceituação da outra decisão possível para o juízo de primeiro grau - a interlocutória - era como "o ato pelo qual o juiz, no curso do processo, resolve questão incidente," conforme a dicção do art. $162, \S 2^{\circ}$ do $\mathrm{CPC} / 73$.

Portanto, se o juízo ao decidir durante o processo somente podia ater-se a resolver incidente, todas as questões sobre o mérito eram postergadas para a sentença, o momento pelo qual o juízo deveria encerrar o processo e sua jurisdição, numa relação evidente entre decisões e conteúdos: (i) interlocutória - incidentes; (ii) sentença - análise do mérito ou extinção sem mérito.

Somada essas conceituações de sentença e decisão interlocutória, não seria possível que o juízo decidisse sobre pedido do autor contrariando o disposto no conceito da sentença - art. $162, \S 2^{\circ}$, conjuntamente com o teor dos arts. 458 , II e 459 , todos do $\mathrm{CPC} / 73$.

Diante da sentença ser o ato decisório que encerrava a prestação jurisdicional com a resolução das questões o enfrentamento, ou não, do mérito, com o acolhimento, no todo ou em parte, do pleito do autor, Liebman entendia que a unicidade da sentença estava presente, mesmo com a mitigação da oralidade ${ }^{23}$.

22 Sobre essa divisão da jurisdição entre conhecimento e execução: "É indiscutível que o Direito Brasileiro vigente foi estruturado com base na ideia de autonomia entre os dois processos, cognitivo e executivo. Tal se deu, até mesmo, pela inegável influência das ideias de Liebman sobre nosso sistema processual." CÂMARA, Alexandre Freitas. Lições de direito processual civil. 25. ed. São Paulo: Atlas, 2014. p. 223/224.

23 "Sendo assim, é importante remontar às bases das ideias de LIEBMAN sobre o princípio da unidade da sentença para verificar se elas podem ou não ser "importadas" para o direito processual civil brasileiro." CORREIA FILHO, Antonio Carlos Nachif. Julgamentos parciais no processo civil. São Paulo, SP, 
Em seu entendimento, para que pudesse ser prolatada uma decisão parcial com os mesmos conteúdos inerentes a um ato sentencial, haveria de ter expressa positivação autorizante, dada a construção de que somente na sentença era momento de decidir o que o autor pediu na demanda.

Mediante essa construção processualística dos códigos anteriores, mais acentuada no de 1939 e mitigada no 1973 , o princípio da unicidade era a regra ${ }^{24}$ e um dogma para a sentença, mesmo diante de um processo complexo objetivamente, com diversas relações jurídicas para serem resolvidas, seja por cumulação de pedidos, seja por pluralidade de partes.

\subsection{A cisão cognitiva como base da especialidade de algumas hipóteses de procedimentos especiais no $\mathrm{CPC} / 73$}

A cisão cognitiva não é, tampouco era, novidade no ordenamento processual brasileiro, contudo, diante da inflexibilidade visualizada pelo legislador anterior sobre a cisão cognitiva no procedimento comum, era vista como quase inexistente, impossível ou indesejada ${ }^{25}$.

Dessa maneira, se a cisão cognitiva não era possível no procedimento comum, algumas situações processuais ensejavam a bipartição da demanda em dois momentos decisórios, justamente pela configuração de uma autonomia entre capítulos distintos da demanda e a necessidade de que o julgamento de cada capítulo fosse julgado em momentos diversos, um antecedente do outro.

Ou seja, mesmo no $\mathrm{CPC} / 73$, se o procedimento comum não admitia a cisão cognitiva, nas situações em que o processo exigia, claramente, o legislador previu

2015. 176 p. Dissertação (Mestrado). Universidade de São Paulo. Programa de Pós-Graduação em Direito. p. 37/38.

24 Sobre a regra da unicidade relacionar-se sobre a impossibilidade de cisão cognitiva e divisão sobre a extinção do processo, com a necessidade de prolação de somente uma decisão: BONÍCIO, Marcelo José Magalhães. Notas dobre a tutela antecipada parcial na nova reforma do Código de Processo Civil. Revista dos Tribunais. Vol. 808, São Paulo: Ed. RT, 2003. p. 74; FONSECA, Rodrigo Garcia da. A arbitragem e a reforma processual da execução. Revista de Arbitragem e Mediação. Vol. 14, São Paulo: Ed. RT, jul/set/2007. p. 34.

25 "afirmava-se que, pelo princípio da unicidade, a sentença não poderia se dispersar ao longo do processo, devendo ser prolatada em momento único, quando acarretaria a extinção da relação jurídica processual." OLIVEIRA FILHO, Silas Dias de. Julgamento fracionado do mérito e implicações no sistema recursal. São Paulo, SP, 2013. 256 p. Dissertação (Mestrado). Universidade de São Paulo. Programa de Pós-Graduação em Direito. p. 65. 
Revista Eletrônica de Direito Processual - REDP.

Rio de Janeiro. Ano 15. Volume 22. Número 2. Maio a Agosto de 2021

Periódico Quadrimestral da Pós-Graduação Stricto Sensu em Direito Processual da UERJ

Patrono: José Carlos Barbosa Moreira (in mem.). ISSN 1982-7636. pp. 736-781

www.redp.uerj.br

hipóteses em procedimentos especiais ${ }^{26}$. Se havia o dogma de que a sentença seguia o princípio da unicidade ${ }^{27}$, com uma só prolação, este somente era pertinente ao procedimento comum, com a normal existência de cisão cognitiva, contudo relegando as previsões positivas para a especialidade dos procedimentos específicos e especiais ${ }^{28}$.

Essa viabilidade existente na cisão cognitiva nos procedimentos especiais, mesmo no $\mathrm{CPC} / 73$, estava na cumulação sucessiva de determinados casos e, ainda, a necessidade de que a resolução do pedido antecedente fosse apartada da decisão sobre o pedido posterior, como na ação de prestação de contas, demarcação e divisão de terras e consignação em pagamento.

$\mathrm{Na}$ ação de prestação de contas havia um procedimento específico para a cognição judicial sobre a obrigação de prestar ou não as contas e, uma vez decidida pela procedência da prestação de contas, abria-se nova fase procedimental para a própria prestação de contas conjuntamente com a apuração de haveres ${ }^{29}$.

26 "verificam-se algumas previsões expressas de julgamentos parciais também no âmbito de determinados procedimentos especiais que se podem denominar bifásicos ou bipartidos." CORREIA FILHO, Antonio Carlos Nachif. Julgamentos parciais no processo civil. São Paulo, SP, 2015. 176 p. Dissertação (Mestrado). Universidade de São Paulo. Programa de Pós-Graduação em Direito. p. 80.

27 Corroborando que o processo civil brasileiro sempre admitiu a cisão cognitiva: "Existem situações que corroboram para a superação do dogma da incindibilidade da sentença: a consignação em pagamento, a ação prestação de contas e a de improbidade administrativa." ARAÚJO, José Henrique Mouta. A resolução parcial de mérito e a coisa julgada progressiva: reflexos no sistema processual como forma de assegurar a brevidade da prestação jurisdicional. Belém, PA, 2004. 302 p. Tese (Doutorado). Universidade Federal do Pará. Programa de Pós-Graduação em Direito. p. 273.

28 Sobre o dogma equivocado da unicidade da sentença e a existência positivada dos procedimentos especiais: "o fato é que tal dogma representa, na verdade, um mito, pois o próprio Código de Processo Civil sempre previu, de forma expressa, situações em que, dentro do mesmo processo e em razão da natureza deste, proferir-se-iam mais de uma sentença, que, sendo sucessivas, na verdade, seriam parciais. Assim, em certa medida, o fracionamento da tutela definitiva não se mostra novidade no sistema processual brasileiro, ainda que até então tenha tido sua incidência limitada a casos específicos." OLIVEIRA FILHO, Silas Dias de. Julgamento fracionado do mérito e implicações no sistema recursal. São Paulo, SP, 2013. 256 p. Dissertação (Mestrado). Universidade de São Paulo. Programa de Pós-Graduação em Direito. p. 66.

29 A cisão cognitiva já era existente na prestação de contas no $\mathrm{CPC} / 73$, conforme Araújo explana: "Já na ação de prestação de contas, movida por quem pretende exigir contas, é possível ocorrer a situação prevista no art. $915, \S 2^{\circ}$, a saber: o réu, uma vez citado, não contesta ou não nega a obrigação de prestar contas. Ocorrendo tais hipóteses, a legislação adjetiva determina o julgamento antecipado da lide, condenando o demandado a prestar as contas no prazo de 48 horas, sob pena de aceitar as contas apresentadas pelo autor. Referido dispositivo legal atinge frontalmente o dogma da indivisibilidade da sentença, por várias razões: I) referido pronunciamento é interlocutório; II) em seguida, adentrar-se-á na segunda fase do procedimento, que envolvendo efetivamente o quantum e a sua referida execução judicial; III) a solução de mérito, a rigor, é dividida em dois momentos: o primeiro ligado ao dever de prestar contas e o segundo, envolvendo o quantum.” ARAÚJO, José Henrique Mouta. A resolução parcial de mérito e a coisa julgada progressiva: reflexos no sistema processual como forma de assegurar a brevidade da prestação jurisdicional. Belém, PA, 2004. 302 p. Tese (Doutorado). Universidade Federal do Pará. Programa de Pós-Graduação em Direito. p. 273. 
Logo, nesse exemplo, o julgamento do pedido antecedente, necessariamente, deve ocorrer em modo apartado do pedido posterior, dada a necessidade, a partir da procedência do primeiro, de um novo procedimento que culmine na possibilidade de julgamento do pedido posterior. Ou seja, a instrução do segundo pedido somente será realizada a partir da procedência do primeiro pedido e, por isso, a necessidade de uma cisão cognitiva da demanda autorizada pela criação de um procedimento especial pertinente a tanto.

A especialidade inerente a esses determinados procedimentos estava justamente na viabilidade de uma cisão cognitiva e a quebra da unicidade da sentença, uma vez que era impossível, a priori, que fosse realizada tal cisão no procedimento comum do ordenamento revogado. Para tanto, a criação de um procedimento específico para atender a essa pertinência e necessidade da situação imaginada pelo legislador.

Outro exemplo de cisão cognitiva nos procedimentos especiais está na ação de demarcação e divisão de terras ${ }^{30}$, com a mesma cumulação de pedidos de modo sucessivo ${ }^{31}$ e com a cisão cognitiva como regra, tanto no CPC/73 quanto no CPC/2015.

Na ação de consignação em pagamento, excepcionalmente, quando houver dúvida sobre o credor a receber, o art. 898 do CPC/73 previa que fosse julgada extinta a obrigação do autor, com a quitação do mesmo, contudo com a necessidade de que prosseguisse a demanda entre os possíveis credores para que fosse instruído o processo e prolatada uma nova decisão, agora uma sentença ${ }^{32}$. Era, ainda sob a égide do CPC/73, uma autêntica cisão cognitiva, com um julgamento parcial e um definitivo posterior.

Dessa maneira, a existência de uma cisão cognitiva não é novidade no processo civil brasileiro, somente não era admissível como técnica possível no procedimento comum, sempre relegada à necessidade de uma expressa previsão legal, escanteando-a para os procedimentos especiais, tornando a cisão cognitiva um procedimento estanque, sem

30 Sobre o fato da ação de demarcação e divisão de terras também ser, ainda no CPC/73, uma cisão cognitiva: REDONDO, Bruno Garcia. Sentença parcial de mérito e apelação em autos suplementares. Revista de Processo. Vol. 160, Ano 33, p. 142-156, São Paulo: Ed. RT, jun/2008. p. 148.

31 O fato da cumulação ser sucessiva não importa na necessidade de que ocorra a cisão, uma vez que é plenamente possível que haja um julgamento conjunto, no mesmo ato decisório, do pedido antecedente e, se procedente, já julgue a parcela consequente.

32 "o ato judicial contendo a declaração de validade e pertinência do depósito (com a consequente exoneração do autor original tanto da obrigação quanto da relação jurídica processual) não é uma simples decisão - mesmo entendida esta como sentença interlocutória de mérito ${ }^{e}$ - mas, sim, verdadeira sentença de mérito, contendo o julgamento do pedido consignatório (art. 269, I) e apelável, portanto" MARCATO, Antonio Carlos. Ação de consignação em pagamento. $6^{a}$ ed. São Paulo: Malheiros, 2001. p. 122/123. 
comunicação com a procedimentalidade comum e a normalidade do entendimento do que seria o básico do processo brasileiro.

A cisão cognitiva era existente, viável e possível, somente o legislador à época do ordenamento processual anterior inserindo-a como uma especialidade procedimental, diferenciando do procedimento comum, específico e autorizante.

\subsection{A antecipação da tutela de pedido incontroverso: 0 art. $273, \S 6^{\circ}$ do $\mathrm{CPC} / 73$ pela Lei $\mathrm{n}^{\circ} \mathbf{1 0 . 4 4 4 / 2 0 0 2}$}

O procedimento comum no ordenamento revogado mantinha-se diante uma rigidez e inflexibilidade pela teoria da unicidade da sentença, com a visão de que somente seria possível a prolação de uma decisão no processo, com a necessidade de que todos os pontos e capítulos da demanda fossem julgados em um só momento.

A Lei $n^{\circ} 10.444 / 2002$ inseriu uma novidade, à época, sobre a antecipação da tutela legal, com a inserção do $\S 6^{\circ}$ ao art. 273 do $\mathrm{CPC} / 73$, com a possibilidade da tutela antecipada também poderá ser concedida quando um ou mais dos pedidos cumulados, ou parcela deles, mostrar-se incontroverso.

Aparentemente, a inclusão de uma hipótese a mais na antecipação da tutela legal parecia criar uma modalidade de tutela provisória em hipótese em que houvesse cumulação de pedidos ou possibilidade de decomposição do pedido em parcelas e, quando houvesse incontrovérsia sobre esse ponto específico. $\mathrm{O}$ intuito, evidentemente, era conceder maior celeridade ao que já pudesse considerado como incontroverso, como uma nova espécie de antecipação da tutela legal ${ }^{33}$.

O primeiro problema sobre essa hipótese recaia no que seria essa incontrovérsia e, ainda, sobre o posicionamento de muitos na doutrina sobre a natureza desta ser por uma tutela definitiva do pedido incontroverso. Esse ponto sobre a incontrovérsia teve redação equivocada, pelo fato de que a incontrovérsia pode ser entendida sobre uma questão não

33 "Disciplinou-se expressamente a possibilidade de mais uma hipótese de concessão da tutela antecipada. Já estavam expressamente previstas as hipóteses de antecipação assecuratória (fundada na situação de urgência - receio de dano irreparável ou de difícil reparação, nos termos do art. 273, I e antecipação punitiva (fundada no abuso do direito de defesa ou manifesto propósito protelatório do réu, nos termos do art. 273, II). A nova hipótese está fundada na incontroversa parcial da demanda." SOUZA, Wilson Alves de. Tutela antecipada em caso de incontrovérsia parcial da demanda: breves comentários à proposta do poder executivo de alteração do $\S 1^{\circ}$ do art. 273 do código de processo civil. In: A segunda etapa da reforma processual civil. Luiz Guilherme Marinoni; Fredie Didier Jr. (Coord.). São Paulo: Malheiros, 2001. p. 54. 
contestada, mas não sobre um pedido. Mesmo que um pedido não seja contestado, não leva à incontrovérsia quanto à sua procedência ${ }^{34}$. Ou seja, a tutela antecipada nesse caso era sobre a incontrovérsia sobre a questão de fato em torno do pedido, não uma incontrovérsia sobre o pedido, como a norma descrevia.

Diante desse prisma, a tutela poderia ser antecipada quando não houvesse controvérsia a ser solucionada sobre os fatos em torno de um pedido, contudo com a necessidade de que outras questões de fato fossem solucionadas para os outros pedidos, ou parcela destes.

Um dos exemplos possíveis utilizados para a explanação sobre a tutela antecipada do pedido incontroverso seria a possibilidade numa cumulação de pedidos sucessivos, com um condicionante e um posterior, a contestação somente versar sobre o pedido posterior, com a notória incontrovérsia do pedido condicionante. Numa demanda de cobrança de um determinado valor e juros sobre a mora desta cobrança inadimplida, se o réu contestasse somente os juros, automaticamente estaria incontroverso o pedido condicionante ou principal, com a discussão permanecendo somente sobre o pedido posterior.

Mas, seria um pedido incontroverso ou um reconhecimento do pedido, o que ensejaria não a procedência em si, porém a homologação do reconhecimento? No entender deste trabalho, mesmo diante do ordenamento revogado, o reconhecimento seria no art. 269, II do CPC/73, não pelo inciso I, ou seja, nesse caso, o reconhecimento não geraria a procedência e sim o reconhecimento do direito do autor pelo réu, o que retiraria do julgamento pelo juízo, somente importando numa homologação desse reconhecimento, não um julgamento de procedência.

34 Sobre isso, Zavaski entendi que não era uma tutela definitiva, mas somente uma antecipação dos efeitos possíveis numa decisão final, com base na incontroversa fática, mas não na incontrovérsia do pedido: "Numa primeira acepção puramente literal poder-se-ia afirmar, assim, que pedido incontroverso seria aquele a cujo respeito não se estabeleceu controvérsia entre as partes. Em outras palavras, para configurar "incontrovérsia", bastaria que o demandado não se opusesse ao pedido do demandante. Pergunta-se, contudo: a mera ausência de oposição significará, por si só, que o pedido é incontroverso para os fins do $\S 6^{\circ}$ ? A resposta, certamente, deve ser negativa. Pode ocorrer, por exemplo, que o demandado não conteste determinado pedido, o qual, contudo, na avaliação do juiz, é manifestamente descabido. Em caso tal, considerando que a sentença final será de improcedência, é lógico concluir que, embora se trate de pedido a cujo respeito não há controvérsia entre as partes, a sua antecipação será inadmissível." ZAVASCKI, Teori. Antecipação da tutela em face de pedido incontroverso. http://www.abdpc.org.br/abdpc/artigos/teori\%20zavascki(2)\%20-formatado.pdf Acesso no dia 26 de março de 2019. 
Revista Eletrônica de Direito Processual - REDP.

Rio de Janeiro. Ano 15. Volume 22. Número 2. Maio a Agosto de 2021

Periódico Quadrimestral da Pós-Graduação Stricto Sensu em Direito Processual da UERJ

Patrono: José Carlos Barbosa Moreira (in mem.). ISSN 1982-7636. pp. 736-781

www.redp.uerj.br

A questão de fato sendo vista como incontroversa permitia ao juízo debruçar-se, desde logo, sobre uma parcela da demanda, sobre um pedido específico que já pudesse ser resolvido por depender somente daqueles fatos incontroversos, mas toda definição jurídica do pedido seria realizada pelo juízo, com a possibilidade de procedência ou improcedência, afinal, a incontrovérsia dos fatos não leva a uma incontrovérsia do pedido ${ }^{35}$, necessariamente. Logo, a ausência de impugnabilidade sobre um ponto fático na contestação levava o juízo a poder decidir pelo art. $273, \S 6^{\circ}$ do $\mathrm{CPC} / 73$, com a antecipação da tutela por causa dessa incontrovérsia nos fatos, alcançando e impactando um dos pedidos ou parcela destes, mas sem tornar o próprio pedido como incontroverso.

No entanto, o próximo problema estava na visão sobre essa decisão ${ }^{36}$, se era uma antecipação da tutela legal, como uma provisoriedade da decisão ou um julgamento definitivo de modo antecipado? Essa discussão ocorria na época da alteração e gerou grande debate na doutrina, com visões diversas sobre o assunto ${ }^{37}$.

35 Nesse sentido da possibilidade de improcedência: "Quem admite a procedência do pedido impede que o juiz julgue, propriamente, o mérito, já que o processo deve ser encerrado com julgamento do mérito somente em virtude de o réu ter admitido que o autor tem razão. Na confissão e na não-contestação, o réu apenas aceita como verdadeiros determinados fatos, o que não implica, automaticamente, em uma sentença de procedência ao autor, já que dos fatos confessados ou não contestados podem não decorrer os efeitos jurídicos pretendidos." MARINONI, Luiz Guilherme. Tutela antecipatória e julgamento antecipado: parte incontroversa da demanda. 5a. ed. São Paulo: Ed. RT, 2003. p. 125.

36 Araújo levantava diversas indagações sobre essa possibilidade, com a visão de que a norma trouxe mais dúvidas do que certezas: "Sob outro prisma, havendo pedidos cumulados, tornando-se incontroverso apenas um deles, a recente alteração processual admite a tutela antecipada do pedido incontroverso. Contudo, como restará enfrentado logo em seguida, algumas perguntas devem ser formuladas: a) ora, se o sistema permite - e até mesmo incentiva - a cumulação simples, por que não permitiria a descumulação? b) se o réu já teve oportunidade de defesa, trata-se de julgamento com base em cognição sumária ou exauriente? c) a decisão interlocutória será em caráter definitivo ou ainda estará sujeita à confirmação quando da prolação da sentença; d) ocorre violação ao princípio do contraditório?" ARAÚJO, José Henrique Mouta. A resolução parcial de mérito e a coisa julgada progressiva: reflexos no sistema processual como forma de assegurar a brevidade da prestação jurisdicional. Belém, PA, 2004. 302 p. Tese (Doutorado). Universidade Federal do Pará. Programa de Pós-Graduação em Direito. p. 198.

37 A doutrina procurou entender corretamente cada possibilidade sobre a alteração no CPC/73 que inseria a tutela antecipada de pedido incontroverso. Sobre este ponto, Oliveira Filho descreve as três formas de análise: "Pois bem. Há, na doutrina pátria, três correntes acerca da natureza jurídica da decisão proferida com fulcro no art. $273, \S 6^{\circ}$, do Código: (i) Trata-se de decisão fundada em cognição exauriente, dotada de definitividade e apta a adquirir a coisa julgada material. Seria hipótese de fracionamento do julgamento do mérito, seja por decisão interlocutória ou por sentença parcial. (ii) Trata-se de decisão fundada em cognição exauriente, mas que não é dotada de definitividade, nem é capaz de transitar materialmente em julgado, visto que o ordenamento brasileiro veda a cisão do julgamento de mérito. Seria hipótese excepcional de concessão de antecipação dos efeitos práticos da tutela, fundada em cognição plena. (iii) Trata-se de decisão fundada em cognição sumária, provisória, revogável e insuscetível de transitar materialmente em julgado, como qualquer outra modalidade de antecipação dos efeitos da tutela, obedecendo às regras processuais gerais pertinentes à categoria." OLIVEIRA FILHO, Silas Dias de. Julgamento fracionado do mérito e implicações no sistema recursal. São Paulo, SP, 
A antecipação da tutela legal tinha a serventia da inversão do ônus do tempo do processo $^{38}$ do autor para o réu, com a possibilidade, dada a urgência do pleito e a demora processual, da prolação de uma decisão que possibilitasse a produção de eficácia imediata a uma tutela jurisdicional ainda provisória. O art. 273 do CPC/73 era calcado nessa visão da possibilidade de antecipar-se os efeitos de uma tutela jurisdicional da sentença para o início ou o meio do processo, justamente para permitir que a urgência não causasse ainda mais prejuízo a quem tivesse uma probabilidade de direito, diante de prova inequívoca.

Já a antecipação incluída posteriormente com base no art. $273, \S 6^{\circ}$ do CPC/73 trabalhava diante um prisma de incontrovérsia e não probabilidade de direito ou prova inequívoca $^{39}$. O entendimento, portanto, estava na falta de discussão sobre as questões de fato sobre um dos pedidos ou parcela destes, com a possibilidade da prolação de uma decisão provisória sobre tal ponto da inicial ou parcela deste.

Para parte da doutrina, essa possibilidade não abria a possibilidade da prolação de uma decisão interlocutória provisória sobre parcela da demanda, mas de uma decisão interlocutória de julgamento parcial da demanda em que houve uma incontrovérsia sobre o pedido. Afora o entendimento adotado neste trabalho de que a incontrovérsia era sobre os fatos relacionantes ao pedido, uma vez que houvesse a falta de questões de fato a serem decididos referentes a um pedido e a permanência de questão ou questões sobre o outro pedido ou parcela, haveria a possibilidade de julgar o mérito da demanda, definitivamente.

Para tanto, a cognição dessa decisão era exauriente ${ }^{40}$, com a prolação de um julgamento completo do que pedido ou da parcela destes, com base no art. $273, \S 6^{\circ}$ do

2013. 256 p. Dissertação (Mestrado). Universidade de São Paulo. Programa de Pós-Graduação em Direito. p. $127 / 129$.

38 Sobre a inversão do ônus do tempo do processo: MITIDIERO, Daniel. Direito fundamental ao julgamento definitivo da parcela incontroversa: uma proposta de compreensão do art. $273, \S 6^{\circ}$ do $\mathrm{CPC}$, na perspectiva do direito fundamental a um processo sem dilações indevidas (art. $5^{\circ}$, LXXVIII, da CF/1988). Revista de Processo. Vol. 149, p. 105-119, São Paulo: Ed. RT, Jul/2007. p. 105.

39 Sobre a mudança da ótica da cognição, não sendo esta de probabilidade, mas de incontrovérsia: "O pronunciamento, portanto, não se dá com base em mera probabilidade, mas com espeque em cognição exauriente, da mesmíssima profundidade apta a autorizar e determinar o julgamento antecipado da lide, consoante o artigo 330, II, do Código.” AMBRIZZI, Tiago Ravazzi. Julgamento fracionado do mérito no processo civil brasileiro. São Paulo, SP, 2014. 231 p. Dissertação (Mestrado). Universidade de São Paulo. Programa de Pós-Graduação em Direito. p. 42.

40 Nesse sentido: "No caso de pronunciamento judicial fundado no $\S 6^{\circ}$ do art. 273 do CPC, a cognição do juiz é exauriente, justamente por decorrer de uma certeza, obtida pela incontrovérsia referida no dispositivo." CUNHA, Leonardo José Carneiro da. O $\S 6^{\circ}$ do art. 273 do CPC: Tutela Antecipada Parcial ou Julgamento Antecipado Parcial da Lide? Revista Dialética de Direito Processual. n. 1, p. 109-126, São Paulo: Dialética, Abril/2003. p. 122. 
CPC/73, importando, portanto, em uma cisão cognitiva da demanda, com um autêntico julgamento parcial do mérito por uma decisão interlocutória, sendo uma antecipação da tutela legal no sentido de bipartir-se da sentença, mas não sendo com um ar de provisoriedade.

Se a cognição era exauriente, consequentemente, a decisão prolatada com base nessa antecipação da tutela com base em pedido incontroverso gerava, caso não recorrida, a formação da coisa julgada ${ }^{41}$. E, de mesmo modo, a executividade era definitiva ${ }^{42}$ e não provisória.

Por outro lado, Zavascki ${ }^{43}$ entendia que a tutela do art. $273, \S 6^{\circ}$ do $\mathrm{CPC} / 73$ não seria um julgamento do mérito da demanda, mas uma mera antecipação do que se poderia julgar posteriormente. Não seria uma decisão interlocutória com a possibilidade de passar em julgado ${ }^{44}$, tampouco que fosse uma decisão definitiva, mas somente uma decisão que antecipava os efeitos de uma futura sentença ${ }^{45}$.

A opção, diante dessa visão, não seria de uma sentença parcial $^{46}$, tampouco uma decisão interlocutória com a possibilidade de trânsito em julgado e formação de coisa julgada, mas uma mera antecipação dos efeitos de uma futura sentença que,

41 "Daí por que tal pronunciamento tem força para gerar coisa julgada material." CUNHA, Leonardo José Carneiro da. O $\S 6^{\circ}$ do art. 273 do CPC: Tutela Antecipada Parcial ou Julgamento Antecipado Parcial da Lide? Revista Dialética de Direito Processual. n. 1, p. 109-126, São Paulo: Dialética, Abril/2003. p. 122.

42 DALL'ALBA, Felipe Camilo. Julgamento antecipado ou antecipação dos efeitos da tutela do pedido incontroverso?. Revista de Processo. Vol. 128, Ano 40, p. 2007-223, São Paulo: Ed. RT, 2005. p. 221.

43 ZAVASCKI, Teori. Antecipação da tutela em face de pedido incontroverso. http://www.abdpc.org.br/abdpc/artigos/teori\%20zavascki(2)\%20-formatado.pdf Acesso no dia 26 de março de 2019.

44 Em sentido diverso, sobre a formação de coisa julgada dessa decisão não recorrida. CALMON DE PASSOS, José Joaquim. Comentários ao código de processo civil. Vol. III, $6^{\text {a }}$ ed. Rio de Janeiro: Forense, 1989.. p. 72.

45 "Sendo assim, também aqui, como nas demais hipóteses de antecipação da tutela, o que se outorga antecipadamente é a eficácia social da futura sentença de procedência, não a jurídico-formal. Em outras palavras: não se condena por antecipação, nem se declara e nem se constitui ou desconstitui. O que se faz, simplesmente, é adiantar os efeitos executivos que poderão decorrer da futura sentença definitiva condenatória, declaratória, constitutiva ou desconstitutiva. Efeitos executivos, entenda-se bem, considerados no sentido amplo: são os efeitos que se passam, não no mundo dos pensamentos, mas no plano da realidade, a saber, os que se destinam ou têm aptidão para produzir ou induzir a manutenção ou a modificação do estado de fato." ZAVASCKI, Teori. Antecipação da tutela em face de pedido incontroverso. http://www.abdpc.org.br/abdpc/artigos/teori\%20zavascki(2)\%20-formatado.pdf Acesso no dia 26 de março de 2019

46 Optando por entender não ser uma sentença parcial, tampouco um julgamento parcial, filiando-se ao que entendia ser uma tutela provisória de pedido incontroverso: "Que pena! O legislador não quis ousar mais, a ponto de autorizar nesses casos um parcial julgamento antecipado do mérito." DINAMARCO, Cândido Rangel. A reforma da reforma. $3^{\mathrm{a}}$ ed. São Paulo: Malheiros, 2002. p. 96. 
provavelmente $^{47}$, pelo alto teor da probabilidade ${ }^{48}$, seria de confirmação da tutela antecipada ${ }^{49}$.

Diante dessa visão, a cognição seria precária, ainda de modo sumário ${ }^{50}$, somente diante dos efeitos do que se pleiteou e não exauriente ${ }^{51}$, a qual somente se daria quando houvesse a confirmação da antecipação na prolação da sentença ${ }^{52}$.

47 "Para a imediata tutela da parte incontroversa do pedido, talvez a melhor solução tivesse sido a da cisão do julgamento, permitindo sentença parcial, mas definitiva, de mérito. Ter-se-ia, com essa solução, a possibilidade de outorgar, relativamente ao pedido incontroverso, a imediata, completa e definitiva tutela jurisdicional. Não foi essa, todavia, a opção do legislador, que preferiu o caminho da tutela antecipada provisória. Com isso, limitou-se o âmbito da antecipação aos efeitos executivos da tutela pretendida." ZAVASCKI, Teori. Antecipação da tutela em face de pedido incontroverso. http://www.abdpc.org.br/abdpc/artigos/teori\%20zavascki(2)\%20-formatado.pdf Acesso no dia 26 de março de 2019.

48 Dois aspectos, todavia, merecem trato destacado: o que diz respeito à proibição de deferir antecipação "quando houver perigo de irreversibilidade do provimento" $\left(\S 2^{\circ}\right)$ e o que trata da "efetivação da tutela antecipada" $\left(\S 3^{\circ}\right)$. Relativamente a tais pontos, é indispensável considerar a natureza especial da tutela prevista no $\S 6^{\circ}$, notadamente o elevado grau de verossimilhança do direito que lhe serve de pressuposto." ZAVASCKI, Teori. Antecipação da tutela em face de pedido incontroverso. http://www.abdpc.org.br/abdpc/artigos/teori\%20zavascki(2)\%20-formatado.pdf Acesso no dia 26 de março de 2019.

49 Julgamento do STJ no sentido de impossibilidade de coisa julgada da tutela antecipada de pedido incontroverso: “(...) não se discute que a tutela prevista no $\S 6^{\circ}$ do artigo 273 do CPC atende aos princípios constitucionais ligados à efetividade da prestação jurisdicional, ao devido processo legal, à economia processual e à duração razoável do processo, e que a antecipação em comento não é baseada em urgência, nem muito menos se refere a um juízo de probabilidade (ao contrário, é concedida mediante técnica de cognição exauriente após a oportunidade do contraditório). Porém, como já dito, por questão de política legislativa, a tutela acrescentada pela Lei $n^{\circ} 10.444 / 02$ não é suscetível de imunização pela coisa julgada. Assim sendo, não há como na fase de antecipação da tutela, ainda que com fundamento no $\S 6^{\circ}$ do artigo 273 do CPC, permitir o levantamento dos consectários legais (juros de mora e honorários advocatícios), que deverão ser decididos em sentença.” STJ. $3^{\text {a }}$ Turma. REsp 1.234.887-RJ, Rel. Min. Ricardo Villas Bôas Cueva, julgado em 19/9/2013.

50 OLIVEIRA FILHO, Silas Dias de. Julgamento fracionado do mérito e implicações no sistema recursal. São Paulo, SP, 2013. 256 p. Dissertação (Mestrado). Universidade de São Paulo. Programa de Pós-Graduação em Direito. p. 138.

51 Oliveira Filho filiava-se a corrente de Zavascki ao entender que a cognição era meramente sumária e com a antecipação dos efeitos da decisão, não com a antecipação da tutela definitiva: "Sendo assim, é possível constatar que a técnica inserta no $\S 6^{\circ}$ do art. 273 é tipicamente uma antecipação dos efeitos da tutela final, e não a antecipação da própria tutela, pois: (i) não é fundada em cognição exauriente, visto que proferida em cenário de ausência de impugnação especificada dos fatos, capaz de gerar tão-somente presunção relativa de veracidade das alegações do autor; (ii) apesar de situação semelhante à da revelia total, não há aqui expressa autorização legal para a concessão de tutela definitiva com base em cognição sumária; (iii) não se destina a solucionar de forma definitiva o litígio; (iv) visa a afastar os efeitos deletérios do tempo causados pelo estado de insatisfação do direito pleiteado." OLIVEIRA FILHO, Silas Dias de. Julgamento fracionado do mérito e implicações no sistema recursal. São Paulo, SP, 2013. 256 p. Dissertação (Mestrado). Universidade de São Paulo. Programa de Pós-Graduação em Direito. p. 146.

52 Entendendo ser uma decisão provisória, sem o condão de transitar em julgado: "Melhor refletindo, a alternativa legal parece-me adequada, pois produz os efeitos práticos pretendidos, sem retirar do juiz a possibilidade de revogar a antecipação por haver concluído, à luz dos elementos dos autos, pela inexistência do direito, mesmo em relação aos fatos incontroversos." BEDAQUE, José Roberto dos 
Apesar de tal inovação e discussão na doutrina, o impacto de tal alteração no cotidiano forense foi pequeno, dada a pouca utilização do instituto, justamente pela indefinição da norma sobre a sua natureza e, ainda, da inclusão como uma tutela provisória, sendo que teria se situado de modo mais correto no tangente a antecipação do julgamento da lide e a possibilidade de decisão parcial, o que não foi feito, deixando uma confusão sobre o instituto e a sua ineficiência ${ }^{53}$.

A inclusão da possibilidade da tutela antecipada do pedido incontroverso quebrava a premissa de unicidade procedimental na norma processual com a existência de um só caminho para a sentença, com a inclusão para que se decidisse, ainda que provisoriamente, um pedido do autor ou de um real julgamento de parcela da demanda já possível de resolução ${ }^{54}$.

\subsection{A alteração no conceito de sentença pela Lei $n^{0} 11.232 / 2005$ e o impacto na abertura para a cisão cognitiva no procedimento comum do $\mathrm{CPC} / 73$}

Se o CPC/73 já não corroborava com o princípio da oralidade nos mesmos moldes do anterior e permitia o julgamento antecipado, com uma nova realidade na formalidade do processo, abrindo a possibilidade da visão pela viabilidade de uma cisão cognitiva, ainda

Santos. Tutela cautelar e tutela antecipada: tutelas sumárias e de urgência (tentativa de sistematização). 3a. ed. São Paulo: Malheiros, 2003. p. 362/363.

53 Didier Jr. defendia que a técnica adotada para a inclusão do art. $273, \S 6 .^{\circ}$ do CPC/73 era uma técnica de julgamento antecipado parcial, não da concessão de uma tutela provisória antecipada de pedido incontroverso: "defender a tese de que se trata este $\S 6 .^{\circ}$ de simples hipótese de antecipação da tutela é retirar-lhe qualquer utilidade. Se o art. 273 do CPC prevê uma tutela antecipada atípica, genérica, inominada, bastando o preenchimento dos seus requisitos, qual seria a utilidade de o legislador dizer que, quando parte do pedido é incontroversa, seria possível a antecipação da tutela? Se apenas se tratasse de uma decisão provisória, essa menção seria ociosa, pois a situação em análise enquadrar-se-ia, à perfeição, na hipótese de abuso do direito de defesa (inc. II) - realmente, a permanência da defesa do réu, no caso, seria manifestamente abusiva, em razão da incontrovérsia." DIDIER JR., Fredie. Inovações na antecipação dos efeitos da tutela e a resolução parcial do mérito. Revista de Processo. Vol. 110, Ano 28, p. 225-251, São Paulo: Ed. RT, 2003. p. 225/226.

54 Sobre essa decisão que era possível pela última redação do art. 273 , $\S 6^{\circ}$ do CPC/73, a norma dizia que era uma espécie de tutela provisória por incontrovérsia, mas a doutrina entendia que o correto seria nomear de uma sentença antecipada, contudo mantinha a necessidade de confirmação dessa tutela antecipada na sentença. No sentido de entender como um julgamento parcial: “À evidencia, para que um ato jurisdicional seja identificado como sentença, é preciso que todo procedimento em primeiro grau desencadeado com o processo seja extinto. Não importa o conteúdo desse ato, mas sim a extinção de todo o procedimento que tramitou perante o juiz de primeira instância. $\mathrm{O}$ sistema processual brasileiro não impede que uma decisão interlocutória, por exemplo, trate de matéria de mérito, não pré-fixando conteúdo para cada tipo de ato judicial." CUNHA, Leonardo José Carneiro da. O $\S 6^{\circ}$ do art. 273 do CPC: Tutela Antecipada Parcial ou Julgamento Antecipado Parcial da Lide? Revista Dialética de Direito Processual. n. 1, p. 109-126, São Paulo: Dialética, Abril/2003. p. 119. 
que tímida, a inclusão do art. $273, \S 6^{055}$ naquele ordenamento corroborou para a defesa dessa cisão ser possível e viável, com a quebra da unicidade como regra estática processual.

Uma outra alteração legal no $\mathrm{CPC} / 73$ que impactou na visão sobre a quebra da unicidade da sentença como regra foi realizada pela Lei $\mathrm{n}^{\circ} 11.232 / 2005$, mediante a nova redação do art. $162, \S 1^{\circ}$ do CPC/73 para os seguintes termos: "sentença é o ato do juiz que implica alguma das situações previstas nos arts. 267 e 269 desta Lei”.

Se antes dessa redação a sentença era aquela que encerrava o processo com ou sem a discussão de mérito, extinguindo na primeira e acolhendo ou não o pedido do autor na segunda, a partir dessa redação, sentença passou a ser uma decisão que versasse sobre os arts. 267 (sem mérito) e 269 (com mérito) do CPC/73.

Retirou-se qualquer menção a encerramento de procedimento ${ }^{56}$, de fase processual ou de prestação jurisdicional, somente com a atinência ao conteúdo decisório, ou julgando extinto, ou julgando o mérito da demanda.

Dessa maneira, qualquer decisão que versasse sobre o mérito ou que extinguisse a lide seria sentença, ainda que não encerrasse o processo ${ }^{5758}$. Logo, se o juiz indeferisse parcialmente a inicial, estaria, pelo conceito ampliado, sentenciando, o que levou à abertura da possibilidade de sentenças parciais $^{59}$.

55 Sobre o tema: ARAÚJO, José Henrique Mouta. Tutela antecipada do pedido incontroverso: estamos preparados para a nova sistemática processual? Revista de Processo. Vol. 116, Ano 29, p. 207-230, São Paulo: Ed. RT, Jul/2004.

56 O intuito da alteração foi para que fosse compatível com um processo sincrético, numa nova concepção processual, sem imaginar outros problemas para a inter-relação com outros institutos. "Em outras palavras, o legislador objetivava a adaptação do conceito à nova realidade do cumprimento de sentenças, sem que houvesse vontade política de permitir o fatiamento do julgamento da lide, o que criaria uma incompatibilidade com o sistema recursal do Código." CARMONA, Carlos Alberto. Ensaio sobre a sentença arbitral parcial. Revista de Processo. Vol. 165, Ano 33, p. 9-28, São Paulo: Ed. RT, Nov/2008. p. 14.

57 Essa visão sobre "encerrar o processo" era trabalhada de modo potencial, não de realmente encerrar o processo, pelo fato de que caberia recurso: "Havendo recurso, a relação processual não se desfaz, prosseguindo na instância recursal. No rigor dos termos, portanto, sentença não é a decisão de primeiro grau que extingue o processo, mas aquela que sempre tem a força de fazê-lo, quando contra ela não se interpõe recurso." SANTOS, Ernane Fidélis. Manual de direito processual civil. 9a. ed. São Paulo: Saraiva, 2002. p. 2006.

58 "o novo art. 267 do CPC continua tendo como eixo de análise a aptidão para o encerramento do processo." DIAS, Jean Carlos. A reforma do CPC e o fim da teoria da unidade da sentença - Lei 11.232/2005. Revista Dialética de Direito Processual. Vol. 40, p. 79-84, São Paulo: Dialética, Jul/2006. p. 81 .

59 "A classificação dos atos judiciais estava amparada exclusivamente nas suas localizações no procedimento. Enquanto a sentença estava ao fim, pondo fim ao procedimento, a decisão interlocutória era decidida no curso do processo. Para tanto, mostrava-se irrelevante saber se o mérito da demanda 
Revista Eletrônica de Direito Processual - REDP.

Rio de Janeiro. Ano 15. Volume 22. Número 2. Maio a Agosto de 2021

Periódico Quadrimestral da Pós-Graduação Stricto Sensu em Direito Processual da UERJ

Patrono: José Carlos Barbosa Moreira (in mem.). ISSN 1982-7636. pp. 736-781

www.redp.uerj.br

Qualquer decisão que tivesse como base os pressupostos processuais para extinção e o acolhimento ou não de pedido do autor seria uma sentença ${ }^{60}$, independentemente da fase processual. Evidentemente que isso proporcionava dúvidas maiores ${ }^{61}$ do que as certezas dessa nova redação, como, por exemplo, a recorribilidade, coisa julgada e execução do que se decidiu, bem como as diretrizes para essa prolação.

A sentença era, por si só, maior do que seu conceito processual antes imaginado, com uma alteração ampliativa e, de certa maneira, assistêmica ${ }^{62}$ dada a existência de mais problemas do que soluções, pelo fato de que o legislador não se preocupou em incluir esse conceito numa visão geral e impacto no $\mathrm{CPC} / 73$ inteiro, deixando o conceito deslocado dentro do sistema.

Todavia, mediante essa conceituação de sentença, abriu-se uma possibilidade legal de entender sentença como todo ato que era atinente aos assuntos dos arts. 267 e 269 do CPC/73, ainda que parcial63, significando o fim da teoria da unicidade da sentença como regra64, mas somente deixando como uma possibilidade processual.

Evidentemente que não se adotou a visão de que fosse possível a prolação de diversas sentenças durante o procedimento de conhecimento, mas com a última redação do

havia ou não sido apreciado." SCARPARO, Eduardo Kochenborger. Sentenças parciais? Considerações a partir de reforma do art. 161, $\S 1^{\circ}$, do CPC. Revista de Processo. n. 148, Ano 32, p. 153-168, São Paulo: Ed. RT, Jun/2007. p. 158.

60 "A partir da reforma, o conceito de sentença de mérito está centrado no exame do pedido, ou nas situações que foram ficcionalmente assemelhadas a ele, e não mais no resultado extinção do processo. Isso quer dizer que, pela atual redação, a análise do mérito poderá ou não levar à extinção.” DIAS, Jean Carlos. A reforma do CPC e o fim da teoria da unidade da sentença - Lei 11.232/2005. Revista Dialética de Direito Processual. Vol. 40, p. 79-84, São Paulo: Dialética, Jul/2006. p. 81.

61 Sobre a conceituação dada pela sentença na Lei $\mathrm{n}^{\circ}$. 11.232/05, Barbosa Moreira não identificava grandes alterações: "Em suma: as recentes reformas não produzem mudanças substanciais na maneira pela qual se identificam os pronunciamentos judiciais e se caracterizam os respectivos regimes. Podem, quando muito, forçar o intérprete a tal ou qual manobra hermenêutica, para acomodar conceitos e flexibilizar arestas.” BARBOSA MOREIRA, José Carlos. A nova definição de sentença (Lei n ${ }^{\circ}$ 11.232). Revista Dialética de Direito Processual. Vol. 39. p. 78-85. São Paulo: Dialética, Jun/2006. p. 84.

62 Sobre o conceito de sentença proposta no CPC/73 pela alteração pela Lei no $11.232 / 05$ : "nem é tecnicamente correta, nem clara, nem - menos que tudo - elegante.” BARBOSA MOREIRA, José Carlos. A nova definição de sentença (Lei n ${ }^{\circ}$. 11.232). Revista Dialética de Direito Processual. Vol. 39. p. 78-85. São Paulo: Dialética, Jun/2006. p. 85.

63 Sobre essa posição de sentenças parciais: "Resta, portanto, inteiramente descartado o critério topológico de diferenciação dos atos decisórios, pois agora, em meio ao procedimento tanto poderão surgir sentenças quanto decisões interlocutórias.” OLIVEIRA, Bruno Silveira. Um novo conceito de sentença. Revista de Processo. Vol. 149, Ano 32, p. 120-138, São Paulo: Ed. RT, Jul/2007. p. 121.

64 Sobre a alteração "O direito positivo torna evidente a superação do princípio da unicidade, de acordo com o qual o exame do mérito deveria ocorrer em apenas uma decisão." SILVA, Ricardo Alexandre. Limites objetivos da coisa julgada e questões prejudiciais. Curitiba, PR, 2016. 218 p. Tese (Doutorado em Direito). Universidade Federal do Paraná. Programa de Pós-Graduação em Direito. p. 47. 
art. $162, \S 1^{\circ}$ do $\mathrm{CPC} / 73$ era certo que diversas decisões eram possíveis de versar sobre matérias que normalmente eram atinentes à sentença, julgando vícios processuais extintivos de parcela da demanda ou julgando parcela do mérito.

Por mais que a discussão passa-se a ser sobre a natureza jurídica dessa decisão ser ou não uma sentença, mediante o conteúdo do art. $162, \S 1^{\circ}$ do $\mathrm{CPC} / 73$, com a opção entre ser uma sentença parcial ou uma decisão interlocutória de mérito, caso se entendesse que sentença era um conceito rígido, abria-se a visão de que outras decisões além da sentença eram passíveis de conter um julgamento que anteriormente só se imaginava quando se encerrava o procedimento, quando se extinguia a prestação jurisdicional.

Apesar de toda essa discussão sobre a natureza jurídica dessas decisões com conteúdos sentenciais parciais, não havia uma definição clara positivada, com discussões doutrinárias sobre o tema.

\section{O PANORAMA ATUAL DA CISÃO COGNITIVA NO CPC/2015}

\subsection{A positivação da cisão cognitiva e a decisão parcial na fase de conhecimento}

Com o advento de uma nova norma processual e novos conceitos de antigos institutos, optou-se por uma positivação da possibilidade da bipartição cognitiva do processo objetivamente complexo ${ }^{65}$.

Uma demanda que tem várias relações jurídicas, seja pela cumulação de pedidos, seja pela pluralidade de partes, almeja, de igual maneira, um julgamento conjunto e uno de todas essas relações no ato sentencial, como uma busca pela unicidade de todas as decisões, contudo sem atrelar-se a impossibilidade de quebra dessa unidade.

65 Nesse sentido, sobre diferentes aspectos da decisão parcial no CPC/2015: ARRUDA, Paulo Gonçalves de. A sentença parcial vista pelos Tribunais e o reflexo do fracionamento do mérito no anteprojeto do novo Código de Processo Civil. Revista de Processo. Vol. 222, Ano 38, p. 257-292, São Paulo: Ed. RT, 2013; MEIRELES, Edilton. Julgamento antecipado parcial do mérito. Revista de Processo. Vol. 252, Ano 41, p. 133-146, São Paulo: Ed. RT, fev/2016; LUCCA, Rodrigo Ramina de. Julgamentos antecipados parciais de mérito. Revista de Processo. Vol. 257. ano 41. p. 125-150. São Paulo: RT, jul/2016; SILVA, Beclaute Oliveira; ARAUJO, José Henrique Mouta; SILVA, I. L. Eficácia do agravo de instrumento na decisão antecipada parcial de mérito. Revista Eletrônica de Direito Processual. v. 1, p. 57-75, 2016; LEMOS, Vinicius Silva. O agravo de instrumento contra decisão parcial de mérito. Revista de Processo. Vol. 259, Ano 41, p. 275-303, São Paulo: Ed. RT, Set/2016; LESSA, Guilherme Thofehrn. Julgamento parcial do mérito e a necessidade de aplicação do procedimento recursal adequado. Revista de Processo. Vol. 281, Ano 43, p. 281-303, São Paulo: Ed. RT, Jul/2018; PEDRON, Flávio Barbosa Quinaud; MILAGRES, Allan. Reflexões sobre o julgamento antecipado parcial do mérito no processo civil e no processo do trabalho. Revista de Processo. Vol. 285, ano 43, p. 273-289, São Paulo: Ed. RT, 2018. 
A demanda pode ser bipartida em seu objeto litigioso, tanto pelo fato de que uma parcela - pedidos ou partes - não estará apta a ser julgada, com a presença de um vício insanável, ou se sanável, sem ter realizado a sanabilidade, julgando sem mérito esse ponto da demanda, quanto de modo a bipartir-se o próprio julgamento do mérito, com a possibilidade de enfrentamento parcial da demanda, com posterior análise do restante do mérito, com um pedido ou parcela deste sendo julgado num momento processual e na sentença o que ainda tiver que ser enfrentado.

Desse modo, o CPC/2015 positivou as decisões interlocutórias parciais, as quais devem ser entendidas como enquadradas nessa espécie de natureza decisória pelo fato de coadunarem com o disposto no art. $203, \S \S 1^{\circ}$ e $2^{\circ}$ do CPC, no tocante à conceituação de sentença $^{66}$ e decisão interlocutória. A primeira será a decisão que encerra a fase de cognição, mediante um julgamento com ou sem o enfrentamento do mérito, já a segunda será qualquer ato decisório do juízo de primeiro grau que não se enquadre na conceituação de sentença, sem encerramento de uma fase.

Diante dessas conceituações, a opção não foi por uma sentença parcial ${ }^{67}$, mas no enquadramento em uma decisão interlocutória parcial, seja de mérito, seja sem mérito.

O CPC/2015 possibilitou a cisão cognitiva do objeto litigioso do processo, sem a necessidade de que haja a unicidade da sentença ${ }^{68}$, com o dever do juízo em julgar as parcelas da demanda que já forem possíveis, dada a existência dos requisitos autorizantes, como a cumulação de pedidos ou partes, a pluralidade de questões de fato e a possibilidade de imediata resolução de uma delas, com a pendência da relação entre uma questão e um dos pedidos ou parcela deste.

66 Sobre o conceito de sentença no CPC atual: "Para o novo Código, sentença é o pronunciamento por meio do qual o juiz, com fundamento nos arts. 485 e 487 do NCPC, põe fim à fase cognitiva do procedimento comum, bem como extingue a execução (art. 203, $\S 1^{\circ}$ ), ou seja, é tanto o ato que extingue o processo sem resolução de mérito como o que o faz resolvendo o mérito da causa." THEODORO JR., Humberto. Curso de direito processual civil. Vol. I, 59 a ed. 2018 [Minha Biblioteca]. Retirado de https://integrada.minhabiblioteca.com.br/\#/books/9788530977764/

$67 \mathrm{Na}$ abertura da possibilidade da cisão cognitiva no CPC/73, muitos admitiam a nomenclatura sentença parcial: MITIDIERO, Daniel. Sentenças parciais de mérito e resolução definitiva fracionada da causa: lendo um ensaio de Fredie Didier Júnior. Ajuris. Porto Alegre, v. 94, p. 39-50, 2004; SCARPARO, Eduardo Kochenborger. Sentenças parciais? Considerações a partir de reforma do art. $161, \S 1^{\circ}$, do CPC. Revista de Processo. n. 148, Ano 32, p. 153-168, São Paulo: Ed. RT, Jun/2007; OLIVEIRA, Bruno Silveira. Um novo conceito de sentença. Revista de Processo. Vol. 149, Ano 32, p. 120-138, São Paulo: Ed. RT, Jul/2007.

68 A unicidade ainda é possível, somente não é mais regra estanque da sentença. 
$\mathrm{O}$ art. 354, parágrafo único permite duas espécies de decisões parciais: (i) as extintivas pela presença de um vício processual impeditivo do julgamento de mérito hipóteses do art. 485 do CPC; (ii) as extintivas de mérito, com base no art. 487, II e III do CPC - prescrição, decadência e as homologatórias de transação, reconhecimento do pedido pelo réu e renúncia do autor ao direito.

A cisão cognitiva é possível para extinguir parcela do objeto litigioso sem efetivamente julgar o mérito, seja pelo fato de que aquela parcela da demanda está eivada de algum vício, seja pelo fato de que o juízo deve reconhecer a prescrição ou decadência parcial ou homologar transação, renúncia ou reconhecimento parcial.

Já no art. 356 do CPC, a cisão cognitiva atinge diretamente o mérito, com a possibilidade de julgamento parcial do pedido ou parcela deste. Se o processo objetivamente complexo permitir que o juízo julgue, por causa do cumprimento dos requisitos para tanto, um dos pedidos cumulados, sem a possibilidade de julgamento completo do objeto litigioso do processo, será prolatada uma decisão interlocutória parcial do mérito.

Um dos requisitos que permite tal possibilidade de julgar parcialmente o mérito é a incontrovérsia sobre os fatos ou a resolubilidade de uma questão de fato, ambos que afetem somente um dos pedidos ou parcela deste, possibilitando um imediato julgamento parcial do mérito. Como não há a resolução integral do objeto litigioso do processo, a cisão cognitiva é a consequência natural da configuração dos requisitos para tanto, com o dever do juízo em prolatar a decisão parcial, com a cindibilidade do processo, com o término da jurisdição sobre parcela deste - ao menos neste grau - e a continuidade no tocante aos demais pontos e as questões de fato necessárias de serem enfrentadas para a completude do julgamento e da jurisdição.

De todo modo, a cisão cognitiva, no CPC/2015, deixa de ser uma mera possibilidade diante da inserção no capítulo de tutela provisória ou antecipação da tutela legal, tampouco como possível somente pela interpretação do conceito da sentença e, também, deixa de ser viável somente nos procedimentos especiais, passando, então, a ser totalmente inserta e pertinente ao ordenamento do procedimento comum do processo civil brasileiro, um caminho procedimental normal e pertinente. 


\subsection{A unicidade da sentença como regra e a decisão parcial como exceção no CPC/2015}

Mesmo diante de uma ampla possibilidade de cisão cognitiva de um processo objetivamente complexo - por decisão parcial com ou sem mérito - o caminho procedimental comum leva a entender que o normal da processualística será almejar uma unicidade do julgamento dos pedidos na sentença.

Se o autor aciona a jurisdição com uma pluralidade de relações jurídicas, a regra será proporcionar que a resolução de todos os pedidos e relações seja no ato sentencial, com o encerramento do procedimento comum, mantendo a existência e o diálogo da teoria da unicidade da sentença no ordenamento processual.

A positivação do art. 356 do CPC para a abertura de uma bipartição cognitiva e procedimental não insere nova regra, tampouco retira a unicidade ${ }^{69}$ como algo a ser buscável no caminho até a decisão final, somente não deve ser um princípio restritivo de que outras alternativas decisórias e procedimentais podem melhor se adequar àquela situação que se apresenta processualmente.

Se houver uma resolução somente parcial sobre as questões de fato, com a configuração de uma bifurcação cognitiva, o juízo deve prolatar a decisão parcial de mérito e prosseguir com o restante da demanda para o julgamento na sentença. De igual maneira deve-se proceder mediante uma bifurcação cognitiva que não seja para julgar o mérito, mas para extinguir somente parcela de uma demanda, com a viabilidade procedimental para o julgamento do restante.

A diferença existente no regramento do CPC/2015 quanto ao CPC/73 está na ausência de uma visão de que a unicidade é algo a ser uno e restringível, sendo somente, em regra, o desejável, mas não mais a base da processualística civil brasileira. Se a situação apresentável, processualmente, necessitar de uma cisão cognitiva sem mérito,

69 A unicidade continua sendo a regra, a sentença ser una é regra e deve ser assim encarada. Gouveia chama a cisão cognitiva ou fracionamento decisional de um acidente processual, mediante as configurações de diversas situações autorizantes. "Isto porque não é da essência do procedimento comum (e de outros que lhe sejam análogos) ter esse fracionamento, algo que lhe é acidental. O fracionamento é uma especialização in concreto do procedimento comum. Sendo oriundo de uma decisão judicial, é fundamental determinar quais são os requisitos para que ocorra, ou, mais propriamente, o que é necessário ao surgimento do direito processual da parte (e, claro, do dever processual do juiz) a ele." GOUVEIA FILHO, Roberto P. Campos. O art. 356, CPC, é base normativa suficiente para regular o

fracionamento decisional? (Final). https://emporiododireito.com.br/leitura/o-art-356-cpc-e-basenormativa-suficiente-para-regular-o-fracionamento-decisional-final Acesso no dia 19 de junho de 2019. 
assim será possível ser prolatada tal decisão. Igualmente se a bifurcação cognitiva for para cindir o mérito, da mesma maneira ocorrerá esta possibilidade, com total viabilidade e positivação.

\subsection{A reedição de procedimentos especiais no $\mathrm{CPC} / 2015$ com a cisão cognitiva como}

\section{base da especialidade}

$\mathrm{Na}$ matéria dos procedimentos especiais, o CPC/2015 não trouxe grandes novidades $^{70}$, com a reedição de vários procedimentos específicos para determinadas matérias, como no ordenamento revogado. No tocante à cisão cognitiva, alguns procedimentos especiais detêm essa especialidade justamente pela permissão dessa cisão, com a divisão da sua procedimentalidade entre uma primeira fase para a resolução das questões sobre um determinado pedido e, se procedente, abre-se uma nova fase em busca da resolução de um novo pedido sucessivo àquele anterior, com a cognição envolta à resolução das questões de fato e de direito pertinentes a esse pedido.

A cisão cognitiva já era possível em procedimentos especiais no $\mathrm{CPC} / 73 \mathrm{e}$, dessa maneira, foi reeditada no CPC/2015 com diversos procedimentos especiais que detêm tão somente a diferenciação do procedimento comum o fato dessa cisão estar em sua normalidade. Esses procedimentos especiais que permitem a cisão cognitiva são: $(i)$ a ação de exigir contas $^{7172}$; (ii) a ação de divisão e demarcação de terras particulares ${ }^{73}$; (iii) a

70 Sobre os procedimentos especiais e suas poucas novidades no CPC/2015: MARCATO, Carlos, Antonio. Procedimentos $\quad$ Especiais. $17^{\mathrm{a}} \quad$ ed. $\quad[$ Grupo $\quad$ GEN]. $\quad$ Retirado de https://grupogen.vitalsource.com/\#/books/9788597013283/

71 Conceituando a necessidade de exigir contas e a possibilidade dessa demanda: "Determinadas pessoas, às quais houver sido confiada a administração ou a gestão de bens ou de interesses alheios, têm a obrigação de prestar contas, quando solicitadas, ou dá-las voluntariamente, se necessário." MARCATO, Carlos, Antonio. Procedimentos Especiais. $17^{\mathrm{a}}$ ed. [Grupo GEN]. Retirado de https:/grupogen.vitalsource.com/\#/books/9788597013283/

72 Sobre os novos aspectos e a mudança na nomenclatura desse procedimento para exigir contas: PEIXOTO, Ravi. Aspectos controvertidos da ação de exigir contas. Revista Dialética de Direito Processual. Vol. 151, p. 105-116, São Paulo: Dialética, 2015.

73 Apesar da existência de todo um procedimento especial para a ação de demarcação e a ação de divisão, com a possibilidade de cumulação entre estas, pode, ainda, ser realizado o direito ali existente de modo extrajudicial: "Possibilidade de demarcação e/ou divisão extrajudicial. Caso os interessados estejam de acordo, e desde que sejam maiores e capazes, poderão proceder com a demarcação e divisão por meio de escritura pública, nos moldes do que preceitua o artigo 571." MAZZEI, Rodrigo; GONÇALVES, Tiago Figueiredo. Comentário ao art. 588. Novo código de processo civil comentado - Tomo II (art. 318 ao art. 770). Orgs: RIBEIRO, Sergio Luiz Almeida; GOUVEIA FILHO, Roberto Pinheiro Campos; PANTALEÃO, Izabel Cristina; GOUVEIA, Lucio Grassi de. Ed. Lualri, São Paulo, 2017. p. 404. 
Revista Eletrônica de Direito Processual - REDP.

Rio de Janeiro. Ano 15. Volume 22. Número 2. Maio a Agosto de 2021

Periódico Quadrimestral da Pós-Graduação Stricto Sensu em Direito Processual da UERJ

Patrono: José Carlos Barbosa Moreira (in mem.). ISSN 1982-7636. pp. 736-781

www.redp.uerj.br

ação de consignação em pagamento com dúvida sobre o real credor; (iv) a ação de dissolução parcial de sociedade ${ }^{74}$ e apuração de haveres ${ }^{75}$.

Todas essas ações com procedimentos especiais no atual ordenamento detém a possibilidade, ainda que em hipóteses excepcionais como na consignação em pagamento, da cisão cognitiva, com a bipartição do procedimento em duas fases, uma para que se alcance o julgamento de um pedido e, posteriormente, o início da instrução do segundo pedido, dada a existência de uma cumulação de pedidos sucessiva.

Sobre esses procedimentos especiais, a consignação em pagamento e a divisão e demarcação de terras particulares foram reeditadas com poucas alterações, mas com a mantença da cisão cognitiva, ainda que somente em algumas hipóteses, como na consignação ou como mera possibilidade de cumulação, como na divisão e demarcação.

A ação de prestação de contas existente no CPC/73 foi trocada pela nomenclatura de exigir contas, dada a visão de que quem pleiteia as contas discute, cognitivamente, o direito a exigência das contas e, somente a posterior, se procedente tal direito, a prestação de contas e apuração de eventuais haveres. Evidentemente que não são grandes as novidades sobre a ação, mas, de igual maneira, a cisão cognitiva é possível, tal qual já era no ordenamento revogado.

74 Sobre a criação de um procedimento especial específico para a dissolução parcial de sociedade: "Na vigência do CPC/1973, adotava-se o entendimento (STJ, REsp 613629/RJ, 26/09/2006) de que as ações de dissolução parcial de sociedade ficariam submetidas ao procedimento ordinário, ainda que fossem analogicamente aplicáveis os artigos 655 à 674 do CPC/1939 - por força do disposto no artigo 1.218, inciso VII, do CPC/1973. Isso porque a dissolução parcial estaria situada no campo da criação doutrinária e jurisprudencial, sem qualquer regramento processual posto, o que, por si só, afastaria a aplicação do rito especial expressamente previsto no CPC/1939 acerca da dissolução total de sociedade. Diferentemente dos códigos que o antecederam, o Código de Processo Civil de 2015 trouxe, dentre os procedimentos especiais, um novo tratamento legal para o que denominou "ação de dissolução parcial de sociedade." SOUZA, Roney José Lemos Rodrigues de. Comentário ao art. 599. Novo código de processo civil comentado - Tomo II (art. 318 ao art. 770). Orgs: RIBEIRO, Sergio Luiz Almeida; GOUVEIA FILHO, Roberto Pinheiro Campos; PANTALEÃO, Izabel Cristina; GOUVEIA, Lucio Grassi de. Ed. Lualri, São Paulo, 2017. p. 414.

75 Julgamento no sentido de ser possível a cumulação entre dissolução parcial de sociedade e apuração de haveres: AÇÃO DE DISSOLUÇÃO PARCIAL DE SOCIEDADE C/C APURAÇÃO DE HAVERES. Decisão que afasta a legitimidade do autor à propositura da demanda. Ação proposta por falecidos sócios da sociedade. Autor que, a despeito de não ser sócio, pode exercer a pretensão de receber o valor patrimonial das quotas dos falecidos sócios, de quem é sucessor. Impossibilidade de o autor, que não é sócio, requerer a dissolução parcial da sociedade. Possibilidade de prosseguimento da ação tão somente para apurar e liquidar os haveres que cabem ao autor, na proporção de sua quota hereditária. Recurso parcialmente provido. TJSP, Agravo de Instrumento $n^{\circ} 2205963-15.2016 .8 .26 .0000,1^{\circ}$ de dezembro de 2016. 
A grande novidade dentre esses procedimentos especiais que permitem a cisão cognitiva é a ação de dissolução parcial de sociedade. O intuito desse procedimento especial foi especificar uma ação específica para a liquidação de uma quota societária com a retirada de um dos sócios, o que não existia no ordenamento anterior, com a necessidade de se utilizar o procedimento comum, o que não garantia a melhor prestação jurisdicional.

Sobre essa ação, o procedimento não será, em regra, com a possibilidade da cisão cognitiva, somente quando houver a cumulação entre a dissolução parcial da sociedade e apuração de haveres ou indenização ${ }^{\mathbf{7 6}}$, com a primeira decisão sobre a retirada do sócio e, se procedente, o início do procedimento para apuração dos valores a serem percebidos, se existentes.

\subsection{As decisões parciais de mérito em algumas hipóteses de procedimentos especiais: cisão cognitiva de mérito diversa do art. 356 do CPC/2015}

A decisão parcial de mérito permite que se biparta o mérito de um processo objetivamente complexo, nos moldes das possibilidades do art. 356 do CPC. Ocorre, portanto, um encerramento parcial da cognição para um dos pedidos ou uma das relações daquela demanda.

A possibilidade da utilização da decisão parcial do mérito deve ser encarada como excepcional $^{77}$, não no sentido de ser um dever do juízo e incentivada a sua aplicabilidade no cotidiano jurídico forense, mas no sentido de que um autor não intenta uma demanda

76 "Cumulação entre dissolução parcial e apuração de haveres (ou indenização). Pode ser ajuizada ação relativa à dissolução e à apuração de haveres, mas admite-se, também, o ajuizamento de ação apenas referente à dissolução parcial, ou apenas para a apuração de haveres." MEDINA, José Miguel Garcia. Novo código de processo civil comentado. $2^{\mathrm{a}}$ ed. São Paulo: Ed. RT, 2015. p. 582.

77 Gouveia Filho explica que essa especialidade está na decisão judicial, não na autorização legal para tanto, o que concordamos. Mesmo um processo objetivamente complexo nasce - em regra, fora os procedimentos especiais específicos de cisão - para serem decididos de modo uno na sentença, contudo há a autorização legal para tanto, mediante os requisitos aqui estudados, construídos e defendidos. A decisão judicial, nos moldes defendidos por Gouveia Filho, que permitirá a cisão e o fracionamento, não a própria legal, não será por força legal, mas amparada na lei, via decisão do juízo. "Por tudo isso, no âmbito do espraiamento sentencial, a hipótese prevista no art. 356, CPC, não pode ser classificável como especialização legal (em virtude de lei, mais propriamente designando), mas sim por força judicial, já que, sem o ato do juiz, não haverá qualquer tipo de fracionamento da decisão, ao contrário do que ocorre com, por exemplo, o procedimento da ação divisória, no qual o fracionamento, estabelecido nos arts. 592, $\S 1^{\circ}, 596$, caput, e $597, \S 1^{\circ}$, todos do CPC, é da sua própria essência. Nele, o especializar ter-se-ia caso ocorresse o exato oposto: a fusão dessas decisões, que, dantes, por lei, estariam fracionadas." GOUVEIA FILHO, Roberto P. Campos. O art. 356, CPC, é base normativa suficiente para regular o fracionamento decisional? $1^{\text {a. }}$ Parte. https://emporiododireito.com.br/leitura/o-art-356-cpc-e-base-normativa-suficiente-para-regular-ofracionamento-decisional-1-parte Acesso no dia 19 de junho de 2019. 
objetivamente complexa com um intuito de que ela seja bipartida em sua cognição. $\mathrm{O}$ intuito é que a ação seja julgada de modo unificado, numa única prestação jurisdicional, na sentença, enfrentando todas as questões de fato e de direito, com o julgamento de todos os pedidos e relações jurídicas.

Nesses moldes, o julgamento unificado na sentença é a regra, a decisão parcial, a exceção.

No entanto, nos procedimentos especiais, teremos delimitadas espécies de procedimentos em que a bipartição não é uma exceção, mas uma regra pertinente ao próprio procedimento, justamente o que o transforma em um procedimento especial, como na ação de exigir contas, divisão e demarcação de terras particulares, consignação em pagamento com real dúvida do credor e dissolução parcial de sociedade com apuração de haveres.

Ou seja, nesses procedimentos específicos, o intuito do autor é na prestação bipartida, diante da ótica de que necessita de um determinado pedido julgado num momento e a abertura da procedimentalidade de um segundo pedido para um outro momento.

A bipartição cognitiva da demanda em seu mérito não é novidade de modo positivado no ordenamento processual pelo CPC/2015 e o art. 356 do CPC, por já existir nos procedimentos especiais, a novidade é a inserção como uma possibilidade normal, corriqueira e regulamentada para o procedimento comum.

Por outro lado, não se pode negar que há um diálogo entre o art. 356 do CPC, suas hipóteses e a possibilidade nos procedimentos especiais, contudo, notadamente, são mundos procedimentais diferentes ${ }^{78}$, apesar de dialógicos ${ }^{79}$. Os procedimentos especiais que detém essa bipartição, como a ação de exigir contas ${ }^{80}$ ou divisão e demarcação de

78 Sobre os procedimentos especiais: "Há procedimentos que são estruturados para que, ao longo de seu (per)curso, mais de uma decisão seja proferida em sucessão, ou seja, a ação processualizada vai sendo julgada paulatinamente, de modo espraiado." GOUVEIA FILHO, Roberto P. Campos; DI SPIRITO, Marco Paulo Denucci. Sobre o negócio jurídico de espraiamento sentencial. Revista Brasileira de Direito Processual - RBDPro | Belo Horizonte, ano 25, n. 100, p. 253-290, out./dez. 2017. p. 277.

79 CABRAL, Antonio do Passo; CUNHA, Leonardo José Carneiro da; DIDIER JR., Fredie. Por uma nova teoria dos procedimentos especiais: dos procedimentos às técnicas. 1a. ed. Salvador: Juspodivm, 2018. . p. 111.

80 Mesmo nos procedimentos especiais que detém a fragmentação do mérito em dois momentos, o pedido é realizado conjuntamente na inicial, somente já se sabe que um pedido terá julgamento temporal posterior ao outro, se procedente: "É o que se tem, por exemplo, na "ação de exigir contas", em que o autor afirma pretender que o réu seja condenado a prestar contas e lhe restituir o saldo favorável que seja apurado. 
Revista Eletrônica de Direito Processual - REDP.

Rio de Janeiro. Ano 15. Volume 22. Número 2. Maio a Agosto de 2021

Periódico Quadrimestral da Pós-Graduação Stricto Sensu em Direito Processual da UERJ

Patrono: José Carlos Barbosa Moreira (in mem.). ISSN 1982-7636. pp. 736-781

www.redp.uerj.br

terras, trabalham com a ótica de que precisam solucionar um problema sucessivo a um outro.

Desse modo, há uma cumulação sucessiva necessária, com um pedido para ser analisado e, se julgado procedente, com a abertura para a cognição do posterior. Mas, há uma diferença entre a cumulação sucessiva no procedimento comum e a dos procedimentos especiais, uma vez que essa primeira cumulação sucessiva trabalha com o intuito de que os dois pedidos sejam julgados no mesmo momento, na sentença e o procedimento, mediante as questões de fato e de direito apresentadas, trabalha para viabilizar que todos os pontos sejam resolvidos unicamente na sentença, como regra. Já na ótica dos procedimentos especiais, os pedidos são resolvidos em sucessividade, contudo em procedimentos diferentes, com um sendo, necessariamente, antecedente $\mathrm{e}$ desconectado, sem a possibilidade de serem julgados de modo unificado.

O diálogo existente entre essa cumulação sucessiva de pedidos e os procedimentos especiais existe, contudo as questões de fato impõem uma diferenciação ${ }^{81}$.

Nos procedimentos especiais, notadamente, o legislador diferencia o procedimento justamente pela constatação imediata de que aquela situação jurídica detém uma questão de fato diferente para cada pedido, uma para o condicionante e outra para o condicionado, sendo que estas serão tratadas temporalmente em momentos diversos.

Parece evidente que, em casos assim, só se pode cogitar da determinação do valor a ser restituído depois da prestação de contas do réu e, portanto, não se pode exigir do autor que formule pedido determinado, sendo admissível o pedido genérico.” CÃMARA. Alexandre Freitas. O novo processo civil brasileiro. $4^{\text {a }}$ ed. Atlas, 2018. [Minha Biblioteca]. Retirado de https://integrada.minhabiblioteca.com.br/\#/books/9788597014426/

81 Há uma aproximação dos institutos do julgamento parcial de mérito e os procedimentos especiais bipartidos legalmente? Obviamente que sim. No entanto, as situações são diferentes. No procedimento comum, o julgamento bipartido é uma possibilidade, mediante uma série de fatos, como cumulação de pedidos, pluralidade de questões de fato, possibilidade de resolução ou incontrovérsia sobre uma delas e pendência sobre outra, com a possibilidade de julgamento de uma parcela da demanda, com a necessidade do aguardo de outra parcela para julgamento pós-instrução. Nos procedimentos especiais que detém essa bipartição, todos esses atributos já são normais e intrínsecos do procedimento, configurados como regramento do procedimento pela percepção do legislador dessa configuração dos requisitos que são possíveis no procedimento comum. Cabral, Cunha e Didier Jr. entendem que essa possibilidade de fracionamento no procedimento comum traz um caráter de especialidade para o procedimento comum, esvaziando o procedimento especial, dada a sua possibilidade no comum, como uma normalidade sistêmica. No entanto, há notadamente diferenças entre os procedimentos em termos de regras e possibilidades. "Após o CPC/2015, essa técnica perdeu seu caráter especial. É que, por força do art. 356, o procedimento comum também permite a solução parcial do mérito, por meio do chamado julgamento antecipado parcial de mérito.” CABRAL, Antonio do Passo; CUNHA, Leonardo José Carneiro da; DIDIER JR., Fredie. Por uma nova teoria dos procedimentos especiais: dos procedimentos às técnicas. 1a. ed. Salvador: Juspodivm, 2018. p. 111/112. 
No procedimento comum, quando há uma cumulação sucessiva de pedidos, a bipartição do mérito depende da possibilidade de bipartição da questão de fato, com as diretrizes apresentadas e a apresentação de uma bifurcação cognitiva, o que pode ou não acontecer, dependendo da situação processual. A regra é que todos os pedidos, ainda que cumulados sucessivamente, sejam julgados no mesmo momento, na mesma sentença.

Numa fixação de premissas, a bipartição da cognição no procedimento comum é exceção, nos procedimentos especiais possíveis é regra ${ }^{82}$.

Evidentemente que o funcionamento da cumulação sucessiva serve para os procedimentos especiais, com a necessidade de que o primeiro pedido seja julgado procedente para que se abra a procedimentalidade do segundo pedido, o que pode levar a um procedimento especial, mesmo com a característica de bifurcação, ser julgado só por uma sentença, contudo seria uma hipótese em que não se julgou o pedido sucessivo, como na ação de exigir contas quando se julga improcedente a exigência de $\operatorname{contas}^{83}$, sem a abertura procedimental para a apresentação destas e apuração de haveres.

A diferença para a cumulação sucessiva e a decisão parcial de mérito no procedimento comum está na sua possibilidade excepcional, com a necessidade de que as questões de fato propiciem essa visão sobre a bifurcação cognitiva e a bipartição da demanda pela independência total ou parcial dessas questões de fato.

O intuito é julgar unicamente, mas pode-se bipartir, já nos procedimentos especiais o intuito é julgar separadamente, em sucessividade decisória e procedimental.

\section{5 $\mathrm{O}$ art. $327, \S^{\circ}$ do $\mathrm{CPC} / 2015$ e a desnecessidade de procedimentos especiais específicos para cisões cognitivas}

82 Sobre a fragmentação do julgamento de mérito como a especialidade de procedimento, ou seja, o que faz com que alguns procedimentos sejam especiais: "Fragmentação do julgamento de mérito. Técnica tradicional de especialização do procedimento é a permissão expressa de fragmentação da decisão do caso, em decisões parciais de mérito, cada qual encerrando uma base distinta do procedimento e correspondendo à solução de uma parcela do litígio." CABRAL, Antonio do Passo; CUNHA, Leonardo José Carneiro da; DIDIER JR., Fredie. Por uma nova teoria dos procedimentos especiais: dos procedimentos às técnicas. 1a. ed. Salvador: Juspodivm, 2018. p. 111.

83 Somente há o prosseguimento da demanda se houver a procedência sobre a exigência das contas: "De acordo com o $\S 5 .^{\circ}$, caso seja julgada procedente a ação de exigir contas, o magistrado condenará o réu para que as preste no prazo de 15 (quinze) dias. Contra esta decisão, é cabível a interposição de agravo de instrumento." THAMAY, Rennan Faria Krüger; MARINHO, Daniel Octávio Silva. Comentário ao art. 550. Novo código de processo civil comentado - Tomo II (art. 318 ao art. 770). Orgs: RIBEIRO, Sergio Luiz Almeida; GOUVEIA FILHO, Roberto Pinheiro Campos; PANTALEÃO, Izabel Cristina; GOUVEIA, Lucio Grassi de. Ed. Lualri, São Paulo, 2017. p. 382. 
O processo pode ser objetivamente complexo, com a junção numa só demanda de diversos pedidos ou relações jurídicas entre pluralidade de partes. No entanto, para ser possível a cumulação de pedidos, o próprio CPC/2015 dispõe requisitos pertinentes, conforme a dicção do art. $327, \S 1^{\circ}$ do CPC são eles: (i) compatibilidade entre si; (ii) mesma competência; (iii) seja adequado para todos os pedidos o tipo de procedimento.

Essa é a regra dos requisitos de cumulação de pedidos.

Sobre a última das regras, sobre a adequação de todos os pedidos no mesmo procedimento, a interpretação usual seria de que todos os pedidos deveriam ser compatíveis ao procedimento comum. No CPC/73, esse procedimento comum era dividido entre ordinário e sumário, o que entedia-se que a lógica era de que essa adequação seria uma diretriz para a cumulação entre os pedidos que pudessem ser cumulados e que fossem adequados a somente um, tanto os pedidos pudessem ser no sumário quanto pudessem ser igualmente ser no ordinário.

Todavia, no CPC/2015 não há de se falar mais em dois procedimentos comuns, dada a inexistência de divisão entre sumário e ordinário, sendo somente um procedimento comum. Logo, essa adequação entre os procedimentos deve ser enfatizada como possível a cumulação de pedidos entre o procedimento comum e o especial.

A regra para a cumulação está na possibilidade de que os pedidos estejam no mesmo procedimento, o que viabilizará a própria cumulação. No entanto, o art. $327, \S 2^{\circ}$ do $\mathrm{CPC}^{84}$ regulamenta a possibilidade de cumulação quando os pedidos forem de procedimentos distintos - comum e especial - e determina o regramento sobre a devida adequação ao procedimento comum $^{85}$, com a adaptabilidade de todos os pedidos para a

84 Sobre o art. $327, \S 2^{\circ}$ do CPC e a necessidade de compatibilização do antigo procedimento sumário e o novo procedimento comum: CERQUEIRA, Társis Silva de. A nova face do procedimento comum do novo Código de Processo Civil diante dos procedimentos especiais: uma proposta de interpretação do Art. 327, § $2^{\circ}$, em combinação com o Art.1.049, parágrafo único, ambos do CPC. Revista de Processo. Vol. 273, Ano 42, p. 95-145, São Paulo: Ed. RT. Nov/2017; PUPPIN, Bárbara Altoé; OLIVEIRA, Michelle Ivair Cavalcanti de. Breves apontamentos sobre o artigo $327 \S 2^{\circ}$ do CPC/2015. In: II Congresso de Processo Civil Internacional. Tutela de Direitos e novas técnicas processuais. Vitória, 2017.

85 Ainda no ordenamento passado, Barbosa Moreira realizava uma ressalva procedimento sobre a escolha sobre os pedidos e tal compatibilização, sugerindo várias hipóteses e, no final, possibilitando todos os pedidos pelo rito ordinário. No CPC/2015 não há o rito ordinário, dada a desnecessidade de diferenciação com o sumário, existindo, portanto, o comum, o que seria o equivalente ao ordinário citado por Barbosa Moreira: "A falta de requisito de compatibilidade entre os pedidos (quando exigível) acarreta o indeferimento da petição inicial, por inepta. (...) Quanto à adequação do procedimento, convém distinguir três hipóteses: a) o autor pretende cumular pedidos para os quais indica, corretamente, ritos 
viabilidade de um só procedimento, aquele que consegue abarcar todos os pedidos, com os cuidados pertinentes a compatibilizar o pedido do procedimento especial para a generalidade do procedimento comum.

E, mesmo diante de tal conversão do especial para o comum, não há impedimento de utilização, para o pedido especial, das técnicas diferenciadas e peculiares daquele procedimento, continuando possíveis e pertinentes para aquela demanda, com as devidas adequações para a sua utilização no procedimento comum, sem essa peculiaridade poder destoar, procedimentalmente, do rito comum, sob pena de inviabilizar a própria cumulação.

Muitas das especialidades constantes nos procedimentos especiais está em algum ponto específico - ou pontos específicos - que diverge do comum, não adotando um procedimento inteiro diferente, mas somente uma parcela deste. A partir dessa percepção, se houver a possibilidade de cumular esse pedido especial com um pedido do procedimento comum, somente realizar-se-á a adaptabilidade da peculiaridade ao que for comum, sem nenhuma incompatibilidade. Um exemplo viável é a possibilidade de cumulação um pedido de indenização com o pleito pela consignação em pagamento ${ }^{86}$, tornando o procedimento comum como a base procedimental, contudo adaptando a viabilidade do ato consignatório para esse rito geral.

A regra do art. $327, \S 2^{\circ}$ do $\mathrm{CPC}$ permite uma melhor compatibilização na cumulação de pedidos de procedimentos diversos, adotando-se o comum como base, sem prejuízo de importar institutos e fases pontuais para aquele pedido especial. Esse ponto é

diversos (erro concernente à cumulabilidade, não à indicação dos procedimentos adequados): é inviável o processo conjunto, mas a inicial pode ser deferida em relação a um dos pedidos, restando a autor - a quem se deve abrir a oportunidade de manifestar-se - destacar o outro para o processamento em separado (...) b) o autor pretende cumular pedidos a que deveriam corresponder ritos diversos, indicando para todos, entretanto, o mesmo rito não-ordinário (erro concernente à indicação de procedimentos adequados): a cumulação é inadmissível (...), cumprindo ao juiz indeferir a inicial no tocante aos pedidos a que corresponda rito diferente do indicado pelo autor (...), a menos que este concorde, sendo possível, em vê-los processados todos pelo rito ordinário (...); c) o autor pretende cumular pedidos a que corresponderiam ritos diversos, indicando para todos o ordinário: se nenhum pedido for com este incompatível, admitir-se-á a cumulação; relativamente ao que o for, será indeferida a inicial." BARBOSA MOREIRA, José Carlos. O novo processo civil brasileiro. 20a. ed. Rio de Janeiro: Forense, 2000. p. 17/18.

86 Sobre o exemplo da adaptação da consignação junto a um procedimento comum, Câmara explicita: “Assim, por exemplo, será possível postular-se a consignação em pagamento do preço de um bem e, no mesmo processo, a condenação do réu a entregar o referido bem, usando-se o procedimento comum sem prejuízo de se admitir a realização do depósito judicial do valor ofertado e, até mesmo, a complementação do depósito insuficiente, técnicas diferenciadas estabelecidas para o procedimento especial da consignação em pagamento." CÃMARA. Alexandre Freitas. O novo processo civil brasileiro. $\quad 4^{\mathrm{a}} \quad$ ed. Atlas, 2018. [Minha Biblioteca]. Retirado de https://integrada.minhabiblioteca.com.br/\#/books/9788597014426/ 
pertinente pela própria visão do que seria o procedimento especial, dada somente a peculiaridade, na maioria das espécies especiais, de algumas diferenças quanto ao comum, convertendo-se, normalmente, em alguma fase processual, ao procedimento comum.

Existem procedimentos especiais cuja a sua existência está voltada para a permissibilidade da cisão cognitiva, o que, mediante a inserção, principalmente, do art. 356 do CPC no ordenamento permitindo ao procedimento comum ser cindido quando o processo for objetivamente complexo, qual o sentido da mantença de um procedimento especial somente para diferenciar do comum sobre essa viabilidade? Essa indagação é pertinente para que os próprios procedimentos especiais que existem somente para propiciar a cisão cognitiva sejam revistos sobre a ótica se necessitam continuar como especiais.

Somente serão incompatíveis os pedidos cumulados quando os procedimentos sejam igualmente inviabilizantes de continuarem no mesmo processo e procedimento, sem a possibilidade de adequação e adaptabilidade entre ambos, o que gerariam a necessidade de opção por um dos pedidos. A cautela existe em uma visão de mão dupla, tanto o procedimento comum de determinado pedido não tornando ineficaz um procedimento especial, como ao inverso, com a especialidade ser tamanha que inviabilize o procedimento comum $^{87}$. Se a regra do o art. $327, \S 1^{\circ}$ do CPC está na necessidade dos pedidos cumulados estarem no mesmo procedimento ${ }^{88}$, o conteúdo do art. $327, \S 2^{\circ}$ do CPC representa a

87 "Só não será possível, então, esta cumulação quando as técnicas diferenciadas forem realmente incompatíveis com o procedimento comum, e seu uso desnaturaria o procedimento especial por completo (como se daria, por exemplo, em algum caso em que se quisesse cumular uma demanda de inventário e partilha com outra de investigação de paternidade, a qual segue o procedimento comum, pois isto desnaturaria completamente o procedimento especial do inventário e partilha)." CÃMARA. Alexandre Freitas. O novo processo civil brasileiro. $4^{\text {a }}$ ed. Atlas, 2018. [Minha Biblioteca]. Retirado de https://integrada.minhabiblioteca.com.br/\#/books/9788597014426/

88 Roque traz uma interpretação pertinente do art. $327, \S 2^{\circ}$, utilizando-o para compatibilizar, de igual maneira, dois pedidos com procedimentos especiais, importando ambos para o procedimento comum. Os dizeres de Roque não somente corroboram o que o dispositivo explicita, mas alçam este para solucionar algo que não está previsto, a existência de dois pedidos de procedimentos especiais: "O terceiro requisito para a cumulação é a adequação do procedimento para todos os pedidos cumulados. Se um dos pedidos ensejar procedimento especial, poderá o autor optar por adotar o procedimento comum, viabilizando a cumulação. Nada obsta, ainda, a redução ao procedimento comum, desde que adequado, mesmo que ambos os pedidos se sujeitem a procedimentos especiais distintos. (...) Mesmo sendo adotado o procedimento comum, as técnicas processuais diferenciadas dos procedimentos especiais a que sujeitam os pedidos podem ser utilizadas, desde que não sejam incompatíveis com o procedimento comum. Assim, por exemplo, abrindo mão o autor de utilizar o procedimento especial das ações possessórias, em princípio, ainda seria possível a concessão da liminar prevista no art. 562 para o pedido de reintegração ou manutenção da posse." ROQUE, André Vasconcelos. Comentários ao art. 327. STRECK, Lenio. (3/2016). Comentários ao código de processo civil. $11^{\mathrm{a}}$ ed. [Minha Biblioteca]. Retirado 
Revista Eletrônica de Direito Processual - REDP.

Rio de Janeiro. Ano 15. Volume 22. Número 2. Maio a Agosto de 2021

Periódico Quadrimestral da Pós-Graduação Stricto Sensu em Direito Processual da UERJ

Patrono: José Carlos Barbosa Moreira (in mem.). ISSN 1982-7636. pp. 736-781

www.redp.uerj.br

exceção, a compatibilização de procedimentos diversos, mas adaptáveis ao utilizarem o comum, sem prejuízo nessa adaptação que contenha a mantença de certas especialidades ${ }^{89}$.

Se essa especialidade for somente a cisão cognitiva, como na ação de exigir contas, haveria a necessidade de toda uma procedimentalidade específica para uma determinada situação processual ou material ou seria amplamente possível no procedimento comum, dada a existência do art. 356 do $\mathrm{CPC}^{90}$ ? A única diferença que se imagina sobre esses pontos - procedimentos especiais para cisão cognitiva e a cisão cognitiva do art. 356 do CPC no procedimento comum - está no primeiro permear a própria procedimentalidade como uma cisão existente e necessária, dada a cumulação sucessiva dos pedidos assim dispor, com a prolação de uma decisão e, se procedente, com a abertura do procedimento para uma outra decisão, agora do pedido condicionado, enquanto na segunda hipótese, também existe essa cumulação sucessiva, contudo há a possibilidade de que a resolução de ambos os pedidos, apesar de sucessivos, ocorra na mesma decisão, sem necessariamente cindir a demanda cognitivamente.

Ou seja, a única diferença entre as cisões cognitivas - do procedimento comum e especial - está na possibilidade de cisão mediante a pluralidade das questões de fatos e a

de https://integrada.minhabiblioteca.com.br/\#/books/9788502635609/; Ou seja, se uma inicial for proposta com dois pedidos pertinentes a procedimentos especiais, o rito de compatibilização será o procedimento comum, salvaguardando, obviamente, as suas peculiaridades, onde procedimentalmente for possível, sem prejudicialidade: Alguns exemplos da incompatibilidade são expostos por Costa: "Aludida redução não será viável, contudo, no caso de ações universais, ou seja, que digam respeito a uma universalidade de bens, como são exemplos o inventário, o arrolamento, a falência e a recuperação judicial, que não admitem o procedimento comum, insuficiente para lidar com todas as demandas ou incidentes que podem surgir em tais situações. Também não será possível a redução se o procedimento especial for criado para atender a determinado interesse público, normalmente envolvendo direitos indisponíveis, como ocorre nas ações de estado (exemplo: interdição) ou de controle concentrado de constitucionalidade." COSTA, Susana Henriques da. Comentário ao art. 327. CABRAL, Antonio do Passo, CRAMER, Ronaldo (orgs.). Comentários ao novo código de processo civil. $2^{\mathrm{a}}$ ed.. [Minha Biblioteca]. Retirado de https://integrada.minhabiblioteca.com.br/\#/books/9788530971441/

89 Essa compatibilização excepcional dos procedimentos, trazendo o comum como base e certas peculiaridades do especial, no entanto essa tentativa não deve ocasionar nenhuma prejudicialidade: "Caso se cumulem pedidos que devam tramitar por procedimentos diversos, devem ambos tramitar pelo procedimento comum. Muitos dos procedimentos especiais o são apenas em sua fase inicial, ou em relação a alguma peculiaridade, e seguem, em sua maior parte, o procedimento comum (p. ex., quanto às ações possessórias, art. 566 do CPC/2015). Assim, não se afasta a observância de técnicas processuais específicas, previstas em procedimentos especiais, desde que compatíveis com o procedimento comum (cf. § 2. ${ }^{\circ}$ do art. 327 do CPC/2015). É o que pode ocorrer, quando cumulam-se pedido de consignação em pagamento e de revisão de cláusulas contratuais (cf. STJ, REsp 464.439/GO, 3. ${ }^{a}$ T., j. 15.05.2003, rel. Min. Nancy Andrighi)." MEDINA, José Miguel Garcia. Novo código de processo civil comentado. $2^{\text {a }}$ ed. São Paulo: Ed. RT, 2015. p. 335.

90 Essa indagação é pertinente e realizada nesta obra: CABRAL, Antonio do Passo; CUNHA, Leonardo José Carneiro da; DIDIER JR., Fredie. Por uma nova teoria dos procedimentos especiais: dos procedimentos às técnicas. 1a. ed. Salvador: Juspodivm, 2018. p. 111. 
resolução de uma e pendência de outra no procedimento comum e essa mesma situação processual ser regra no procedimento especial. Enquanto o primeiro trabalha na busca pela unicidade, com a cisão como alternativa, o segundo trabalha com a cisão cognitiva como a busca almejada pelo autor no procedimento.

Dessa maneira, apesar de cisões cognitivas serem existentes nos dois procedimentos, os especiais que existem somente para possibilitar tais cisões tornam-se desnecessários com o incremento na legislação de um artigo do porte e conteúdo do art. 356 do CPC, ressalvando somente que para determinadas situações materiais e relações jurídicas o procedimento que utiliza o citado artigo pode ser a regra ao invés da exceção, o que torna esses procedimentos desnecessários sob o prisma de importarem somente serem especiais pela cisão cognitiva.

\section{ASPECTOS CONCLUSIVOS}

A cisão cognitiva no processo civil brasileiro é uma realidade. Os arts. 354, parágrafo único e 356, ambos do CPC/2015, permitem que um processo objetivamente complexo seja cindido cognitivamente, seja por uma decisão parcial de mérito, seja por uma decisão parcial sem mérito. Se uma demanda tem dois ou mais pedidos ou duas ou mais relações jurídicas, se uma delas pode, desde logo, ser julgada, não há motivos para que se prolongue essa prestação jurisdicional para a prolação de uma só sentença.

A teoria da unicidade da sentença não deixou de existir no $C P C / 2015$. Num processo objetivamente complexo, o procedimento comum é formado para que esta espécie de processo complexo seja decidido todo em uma só sentença. Ou seja, a unicidade da sentença é a regra, é o caminho natural para o processo, contudo somente altera-se que a cisão cognitiva é totalmente possível e viável no processo civil brasileiro, num diálogo com a própria procedimentalidade, numa exceção plausível e viável.

O estudo perpassou a história evolutiva da cisão cognitiva e a sua viabilidade no processo civil brasileiro, com a relegação desta para o procedimento especial no CPC/73, sendo possível somente em determinados procedimentos. Com alterações realizadas no ordenamento - Lei $\mathrm{n}^{\circ}$ 10.444/2002 e Lei $\mathrm{n}^{\circ}$. 11.232/2005 - a cisão cognitiva passou a ser cada vez mais viável e possível, seja pela existência de uma tutela antecipada do pedido incontroverso, seja por uma sentença que não estava mais atrelada ao fim do processo. 
Com toda essa evolução, a indagação na doutrina era a possibilidade de prolações de sentenças parciais e a sua viabilidade, com defesas positivas e negativas. No entanto, mediante o CPC/2015 e a positivação dos dispositivos autorizantes, a decisão parcial é uma realidade, seja julgando o mérito de modo parcial, seja extinguindo parcela da demanda.

A cisão cognitiva faz parte do procedimento comum no CPC/2015.

Esse ponto leva a reflexão dos diálogos dos procedimentos especiais específicos para a prolação de duas decisões de mérito e a própria cisão cognitiva no procedimento comum. Afinal, se o procedimento comum contempla a cisão cognitiva, não há mais motivos para que exista um procedimento específico que seja especial somente por possibilitar uma cisão cognitiva.

Essas são as reflexões e aspectos conclusivos do estudo sobre a cisão cognitiva no tempo e a evolução histórica do instituto. O CPC/2015 possibilitou um grande avanço da matéria, mediante a positivação desta.

\section{REFERÊNCIAS}

AMBRIZZI, Tiago Ravazzi. Julgamento fracionado do mérito no processo civil brasileiro.

São Paulo, SP, 2014. 231 p. Dissertação (Mestrado). Universidade de São Paulo. Programa de Pós-Graduação em Direito.

ARAÚJO, José Henrique Mouta. A resolução parcial de mérito e a coisa julgada progressiva: reflexos no sistema processual como forma de assegurar a brevidade da prestação jurisdicional. Belém, PA, 2004. 302 p. Tese (Doutorado). Universidade Federal do Pará. Programa de Pós-Graduação em Direito.

. Tutela antecipada do pedido incontroverso: estamos preparados para a nova sistemática processual? Revista de Processo. Vol. 116, Ano 29, p. 207-230, São Paulo: Ed. RT, Jul/2004.

ARRUDA ALVIM. Manual de Direito Processual Civil. Vol. II, 6ª ed., São Paulo: Ed. RT, 1997.

ARRUDA, Paulo Gonçalves de. A sentença parcial vista pelos Tribunais e o reflexo do fracionamento do mérito no anteprojeto do novo Código de Processo Civil. Revista de Processo. Vol. 222, Ano 38, p. 257-292, São Paulo: Ed. RT, 2013 
BARBOSA MOREIRA, José Carlos. O novo processo civil brasileiro. Ed. Forense. $18^{\circ}$. ed. Rio de Janeiro. 1996.

. A nova definição de sentença (Lei $n^{\circ}$. 11.232). Revista Dialética de Direito Processual. Vol. 39. p. 78-85. São Paulo: Dialética, Jun/2006.

. Sentença Objetivamente Complexa, Trânsito em Julgado e Rescindibilidade.

Revista Dialética de Direito Processual. Vol. 45, São Paulo: Dialética, dez/2006.

BEDAQUE, José Roberto dos Santos. Tutela cautelar e tutela antecipada: tutelas sumárias e de urgência (tentativa de sistematização). $5^{\text {a }}$ Ed. São Paulo: Malheiros, 2009.

BONÍCIO, Marcelo José Magalhães. Notas dobre a tutela antecipada parcial na nova reforma do Código de Processo Civil. Revista dos Tribunais. Vol. 808, São Paulo: Ed. RT, 2003. p. 74; FONSECA, Rodrigo Garcia da. A arbitragem e a reforma processual da execução. Revista de Arbitragem e Mediação Vol. 14, São Paulo: Ed. $\mathrm{RT}, \mathrm{jul} / \mathrm{set} / 2007$.

CABRAL, Antonio do Passo; CUNHA, Leonardo José Carneiro da; DIDIER JR., Fredie. Por uma nova teoria dos procedimentos especiais: dos procedimentos às técnicas. 1. ed. Salvador: Jus Podivm, 2018.

CALMON DE PASSOS, José Joaquim. Comentários ao Código de Processo Civil. Vol. 3. 9. ed. Rio de Janeiro: Forense, 2004.

CÂMARA, Alexandre Freitas. Lições de direito processual civil. 9a. ed. Rio de Janeiro: Lumen Juris, 2003.

. O Novo Processo Civil Brasileiro, $4^{a}$ edição. [Minha Biblioteca]. Retirado de https://integrada.minhabiblioteca.com.br/\#/books/9788597014426/.

CARMONA, Carlos Alberto. Ensaio sobre a sentença arbitral parcial. Revista de Processo. Vol. 165, Ano 33, p. 9-28, São Paulo: Ed. RT, Nov/2008.

CERQUEIRA, Társis Silva de. A nova face do procedimento comum do novo Código de Processo Civil diante dos procedimentos especiais: uma proposta de interpretação do Art. 327, § 2º em combinação com o Art.1.049, parágrafo único, ambos do CPC Revista de Processo. Vol. 273, Ano 42, p. 95-145, São Paulo: Ed. RT. Nov/2017.

CHIOVENDA, Giuseppe. Ensayos de derecho procesal civil. Vol. I, p. 351-372, Buenos Aires: Ediciones Jurídicas Europa-América, 1949. 
Instituições de Direito Processual Civil. Vol. III. 2 ${ }^{\text {a }}$ Ed. São Paulo: Saraiva, 1965.

CINTRA, Antônio Carlos de Araújo; GRINOVER, Ada Pallegrini; DINAMARCO,

Cândido Rangel. Teoria Geral do Processo. 20ª ed. São Paulo: Malheiros, 2004.

COSTA, Susana Henriques da. CABRAL, Antonio Passo, CRAMER, Ronaldo (orgs.). Comentários ao Novo Código de Processo Civil, $2^{a}$ edição. Método, 06/2016. [Minha Biblioteca].

Retirado de https://integrada.minhabiblioteca.com.br/\#/books/9788530971441/ .

CORREIA FILHO, Antonio Carlos Nachif. Julgamentos parciais no processo civil. São Paulo, SP, 2015. 176 p. Dissertação (Mestrado). Universidade de São Paulo. Programa de Pós-Graduação em Direito.

CUNHA, Leonardo José Carneiro da. O $\S 6^{\circ}$ do art. 273 do CPC: Tutela Antecipada Parcial ou Julgamento Antecipado Parcial da Lide? Revista Dialética de Direito Processual. n. 1, p. 109-126, São Paulo: Dialética, Abril/2003.

DALL“ALBA, Felipe Camilo. Julgamento antecipado ou antecipação dos efeitos da tutela do pedido incontroverso? Revista de Processo, Vol. 128, Ano 40, p. 2007-223, São Paulo: Ed. RT, 2005.

DIDIER JR., Fredie. Inovações na antecipação dos efeitos da tutela e a resolução parcial do mérito. Revista de Processo. Vol. 110, Ano 28, p. 225-251, São Paulo: Ed. RT, 2003.

Os três modelos de direito processual: inquisitivo, dispositivo e cooperativo. Revista de Processo. Vol. 198, Ano 36, p. 213-225, São Paulo: Ed. RT, 2011.

DIDIER JR., Fredie; BRAGA, Paula Sarno; OLIVEIRA, Rafael Alexandria de. Curso de processo civil. Vol. 2. 10.ed. Salvador: JusPodivm, 2015.

DINAMARCO, Cândido Rangel. Capítulos de sentença. $3^{\text {a }}$. ed. São Paulo: Malheiros, 2008.

A reforma da reforma, São Paulo, Malheiros, 2002.

GONÇALVES, Tiago Figueiredo. Comentário ao art. 588. Novo Código de Processo Civil Comentado - Tomo II (art. 318 ao art. 770). Orgs: RIBEIRO, Sergio Luiz Almeida; GOUVEIA FILHO, Roberto Pinheiro Campos; PANTALEÃO, Izabel Cristina; GOUVEIA, Lucio Grassi de. Ed. Lualri, São Paulo, 2017. 
GOUVEIA FILHO, Roberto P. Campos; DI SPIRITO, Marco Paulo Denucci. Sobre o negócio jurídico de espraiamento sentencial. Revista Brasileira de Direito Processual - RBDPro | Belo Horizonte, ano 25, n. 100, p. 253-290, out./dez. 2017.

GRECO, Leonardo. A teoria da ação no processo civil. São Paulo: Dialética, 2003.

LEMOS, Vinicius Silva. O agravo de instrumento contra decisão parcial de mérito. Revista de Processo. Vol. 259, Ano 41, p. 275-303, São Paulo: Ed. RT, Set/2016.

LESSA, Guilherme Thofehrn. Julgamento parcial do mérito e a necessidade de aplicação do procedimento recursal adequado. Revista de Processo. Vol. 281, Ano 43, p. 281303, São Paulo: Ed. RT, Jul/2018.

LUCCA, Rodrigo Ramina de. Julgamentos antecipados parciais de mérito. Revista de Processo. Vol. 257. ano 41. p. 125-150. São Paulo: RT, jul/2016.

MARCATO, Antonio Carlos. Ação de consignação em pagamento. 6 ${ }^{a}$ ed. São Paulo: Malheiros, 2001.

. Procedimentos Especiais, $17^{a}$ edição. [Grupo GEN]. Retirado de https://grupogen.vitalsource.com/\#/books/9788597013283/

MARINHO, Daniel Octávio Silva. Comentário ao art. 550. Novo Código de Processo Civil Comentado - Tomo II (art. 318 ao art. 770). Orgs: RIBEIRO, Sergio Luiz Almeida; GOUVEIA FILHO, Roberto Pinheiro Campos; PANTALEÃO, Izabel Cristina; GOUVEIA, Lucio Grassi de. Ed. Lualri, São Paulo, 2017.

MARINONI, Luiz Guilherme. Técnica processual e tutela dos direitos. São Paulo: Ed. RT, 2004. p. 141/142.

. Tutela antecipatória e julgamento antecipado: parte incontroversa da demanda. 5 . ed. São Paulo: Ed. RT, 2003.

MARQUES, José Frederico. Manual de direito processual civil, vol. 2. $9^{a}$ ed. São Paulo: Saraiva, 1987.

MEDINA, José Miguel Garcia. Novo código de processo civil comentado. $2^{\mathrm{a}}$ Edição. RT: São Paulo. 2015.

MEIRELES, Edilton. Julgamento antecipado parcial do mérito. Revista de Processo. Vol. 252, Ano 41, São Paulo: Ed. RT, fev/2016

MITIDIERO, Daniel. Direito fundamental ao julgamento definitivo da parcela incontroversa: uma proposta de compreensão do art. 273, $\S 6^{\circ}$ do $\mathrm{CPC}$, na 
perspectiva do direito fundamental a um processo sem dilações indevidas (art. $5^{\circ}$, LXXVIII, da CF/1988). Revista de Processo. Vol. 149, p. 105-119, São Paulo: Ed. RT, Jul/2007.

OLIVEIRA, Bruno Silveira. Um novo conceito de sentença. Revista de Processo. Vol. 149, Ano 32, p. 120-138, São Paulo: Ed. RT, Jul/2007.

OLIVEIRA FILHO, Silas Dias de. Julgamento Fracionado do Mérito e Implicações no Sistema Recursal. São Paulo, SP, 2013. 256 p. Dissertação (Mestrado). Universidade de São Paulo. Programa de Pós-Graduação em Direito.

PEDRON, Flávio Barbosa Quinaud; MILAGRES, Allan. Reflexões sobre o julgamento antecipado parcial do mérito no processo civil e no processo do trabalho. Revista de Processo. Vol. 285, ano 43, p. 273-289, São Paulo: Ed. RT, 2018.

PEIXOTO, Ravi. Aspectos controvertidos da ação de exigir contas. Revista Dialética de Direito Processual. Vol. 151, p. 105-116, São Paulo: Dialética, 2015.

PUPPIN, Bárbara Altoé; OLIVEIRA, Michelle Ivair Cavalcanti de. Breves apontamentos sobre o artigo $327 \S 2^{\circ}$ do $\mathrm{CPC} / 2015$. In: II Congresso de Processo Civil Internacional. Tutela de Direitos e novas técnicas processuais. Vitória, 2017.

REDONDO, Bruno Garcia. Sentença parcial de mérito e apelação em autos suplementares. Revista de Processo, n. 160, Ano 33, p. 142-156, São Paulo: Ed. RT, jun/2008.

ROQUE, André Vasconcelos. STRECK, Lenio. Comentários ao código de Processo Civil, $11^{a}$ edição. Saraiva, 3/2016. [Minha Biblioteca]. Retirado de https://integrada.minhabiblioteca.com.br/\#/books/9788502635609/

SANT'ANNA, Paulo Afonso de Souza. Sentença parcial. Revista de Processo. Vol. 151, Ano, 33, p. 150-184, São Paulo: Ed. RT, 2007.

SANTOS, Ernane Fidélis. Manaus de direito processual civil. 9a . ed. São Paulo: Saraiva, 2002. p. 2006.

SCARPARO, Eduardo Kochenborger. Sentenças parciais? Considerações a partir de reforma do art. 161, $\S 1^{\circ}$, do CPC. Revista de Processo. n. 148, Ano 32, p. 153-168, São Paulo: Ed. RT, Jun/2007.

SOUZA, Wilson Alves de. Tutela antecipada em caso de incontrovérsia parcial da demanda: breves comentários à proposta do poder executivo de alteração do $\S 1^{\circ}$ do 
art. 273 do código de processo civil. In: A segunda etapa da reforma processual civil.

Luiz Guilherme Marinoni e Fredie Didier Jr. (Coord.). São Paulo: Malheiros, 2001. SOUZA, Roney José Lemos Rodrigues de. Comentário ao art. 599. Novo Código de Processo Civil Comentado - Tomo II (art. 318 ao art. 770). Orgs: RIBEIRO, Sergio Luiz Almeida; GOUVEIA FILHO, Roberto Pinheiro Campos; PANTALEÃO, Izabel Cristina; GOUVEIA, Lucio Grassi de. Ed. Lualri, São Paulo, 2017.

SILVA, Ricardo Alexandre. Limites objetivos da coisa julgada e questões prejudiciais. Curitiba, PR, 2016. 218 p. Tese (Doutorado em Direito). Universidade Federal do Paraná. Programa de Pós-Graduação em Direito.

SILVA, Beclaute Oliveira; ARAUJO, José Henrique Mouta; SILVA, I. L. Eficácia do agravo de instrumento na decisão antecipada parcial de mérito. Revista Eletrônica de Direito Processual, v. 1, p. 57-75, 2016.

THAMAY, Rennan Faria Krüger; MARINHO, Daniel Octávio Silva. Comentário ao art. 550. Novo Código de Processo Civil Comentado - Tomo II (art. 318 ao art. 770). Orgs: RIBEIRO, Sergio Luiz Almeida; GOUVEIA FILHO, Roberto Pinheiro Campos; PANTALEÃO, Izabel Cristina; GOUVEIA, Lucio Grassi de. Ed. Lualri, São Paulo, 2017.

THEODORO JR., Humberto. Curso de Direito Processual Civil - Vol. I, $60^{a}$ edição. [Grupo GEN]. Retirado de https://grupogen.vitalsource.com/\#/books/9788530984342/

WATANABE, Kazuo. Da cognição no processo civil. 3 ed. revista e atual. São Paulo: Perfil, 2005. p. 67

ZAVASCKI, Teori. Antecipação da tutela em face de pedido incontroverso. http://www.abdpc.org.br/abdpc/artigos/teori\%20zavascki(2)\%20-formatado.pdf Acesso no dia 26 de março de 2019. 